\title{
At kunne skelne lys fra lygtemænd
}

\author{
Om J. W. Marckmanns Fortegnelse over Skrifter til \\ Lasning for Menigmand ${ }^{1}$
}

Af Svend Bruhns og Anders Ørom

Selskabet for Trykkefrihedens rette Brug og folkeoplysningen

Selskabet for Trykkefrihedens rette Brug blev stiftet i marts 1835 . Det var den første politiske forening efter århundredeskiftet.

Selskabet udsprang af et initiativ fra en gruppe embedsmænd, borgere og småborgere, der gennem en petition anmodede kongen om ikke at skærpe censuren. Baggrunden var, at pressen i begyndelsen af 1830rne havde kritiseret trykkefrihedslovgivningen og andre politiske forhold.

Forordningen af 27 . september 1799 , der indskrænkede trykkefriheden kraftigt, var det juridiske grundlag for trykkefrihedsspørgsmål frem til enevældens ophør. Forordningens hovedsigte var at standse offentlig diskussion og kritik af enevældens regeringsform og forfatning.

Pressen havde i 1830rne 'forbrudt' sig mod denne forordning; embedsmænd og folk fra borgerskabet var begyndt at stille spørgsmålstegn ved trykkefriheden. Den folkekære konge, Frederik den Sjette, blev forarget, og "(...) da Skrivefrækheden .... mere og mere tager Overhaand " anlagde regeringen sag mod flere skribenter og truede med at indføre egentlig (forhånds)censur.

Svend Bruhns, ass. fagleder; Anders Ørom, lektor. Danmarks Biblioteksskole, Langagervej 4, 9220 Aalborg $\varnothing$. 
Petitionen fra den ovennævnte kreds, trykkefrihedsadressen, blev underskrevet af over 500 personer og stilet til kongen. Adressen var holdt $i$ en meget underdanig tone og var blot en bøn om, at kongen ville bevare den trykkefrihed, man havde. Der var altså ikke tale om at forlange reel trykkefrihed $i$ landet.

Kongen svarede: "(...) thi ligesom Vor landsfaderlige Opmærksomhed stedse har været henvendt paa at bidrage alt, hvad der stod i Vor kongelige Magt, til at virke for Folkets og Statens Vel, saaledes kan heller ingen uden Vi alene være i Stand til at bedømme, hvad der er begges sande Gavn og Bedste. ${ }^{2}$

Den store tilslutning til trykkefrihedsadressen viste, at der var grundlag for en organisation, og Selskabet for Trykkefrihedens rette Brug kunne oprettes $\mathrm{i}$ en situation, hvor det kongelige ' $\mathrm{Vi}$ alene vide' ikke havde ført til skærpede censurbestemmelser.

Trykkefrihedsselskabet fik hurtigt mange medlemmer. Allerede i april 1836 var der indskrevet 2255. 53\% af medlemmerne var fra København, 35\% fra øerne og $12 \%$ fra Jylland. ${ }^{3}$ Senere skete der en forskydning bort fra københavnske medlemmer; men det generelle billede er, at den geografiske sammensætning afspejler de kultur- og oplysningsmæssige forhold i Danmark. Centrum er København, og øerne var mere "oplyste" end det mørke Jylland.

Socialt set dominerer embedsmandsstanden og borgerskabet i 1836, og selv om der sker mindre forskydninger bort fra samfundets øverste lag, forbliver embedsmandsstanden og borgerskabet langt de vægtigste og mest betydningsfulde grupper i Selskabet. I 1836 var den sociale profil således: ca. $36 \%$ embedsmænd, ca. $30 \%$ handlende og håndværkere (de handlende spændte fra grossistniveau til detailhandel), knap 20\% fra liberale erhverv. 3\% var godsejere og proprietærer og $2 \frac{1}{2} \%$ var bønder. ${ }^{4}$ Selskabets medlemmer repræsenterede således de dannelseskulturbærende lag, den offentlige administration og de dynamiske områder inden for næringslivet.

I Selskabet var forskellige politiske anskuelser repræsenteret: konservative, moderate og liberale. De politiske forskelle var markante. Den konservative fløj, med bl.a. H.C. Ørsted og Sibbern, var egentlig tilfreds med landets politiske status, herunder den herskende reelle censur, der forhindrede 'misbrug' af pressen, såsom 
offentliggørelse af oprørske, anstødelige, blasfemiske eller injurierende skrifter. Den progressive fløj i Selskabet, heriblandt Orla Lehmann og D. G. Monrad, ønskede en ændring af magtforholdene i samfundet, herunder reel trykkefrihed.

Den gyldne middelvej karakteriserede Selskabets politik frem til 1843/44, men da venstrefløjen herefter overtog ledelsen af Selskabet, og Monrad blev redaktør af dets tidsskrift Dansk Folkeblad, kom problemerne med censuren. Bladet blev beslaglagt flere gange.

Den nye, progressive bestyrelse ville imidlertid samle de beslaglagte artikler og udgive dem i bogform, men drøftede på et tidspunkt, om man skulle vente med at udgive bogen, til der var artikler nok til mere end 24 ark, "(...) saa at man kunne være sikker for, at den ikke blev beslaglagt, eller om man, stolende paa, at ingen Beslaglæggelse ville skee, skulde udgive den tidligere med et mindre Arketal. « ${ }^{5}$ Den såkaldte trykkefrihed gik nemlig ud på, at det ganske vist var tilladt at trykke næsten hvad som helst; men inden udgivelsen skulle skrifter på 24 ark eller mindre censureres. Og hvis der så var noget, der stødte censor, kunne han beslaglægge hele oplaget. I givet fald en dyr historie for udgiverne.

Bogen med de beslaglagte artikler udkom i 1844 under titlen Gjengangeren, redigeret af Monrad og på 447 sider in $12^{\circ} !$ - altså langt over 24 ark i kraft af formatet.

Kultur- og oplysningspositioner $i$ Trykkefrihedsselskabet

Som der var flere politiske positioner, var der naturligvis også flere holdninger til kultur og oplysning. En af disse var funderet i oplysningstidens rationalisme, en anden var præget af den nationalromantiske guldalderkultur. Men de har det fælles, at oplysningen både skulle omfatte det statsborgerlige, det samfundsborgerlige og det menneskelige område.

Dette kan ses af Selskabets formål, hvor der lægges megen vægt på folkeoplysning:

"\$1: Selskabets Formaal er ved de Midler, der staar i dets Magt, at fremme Trykkefrihedens rette Brug, modarbejde dens Misbrug og saaledes virke til Folkeoplysning. 


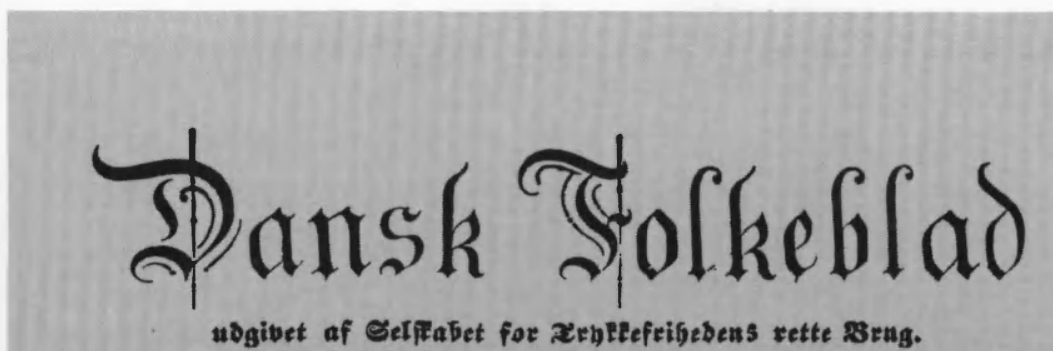

\begin{tabular}{|c|c|}
\hline goe gratg. & 8retsag \$. 28. 2hai 1841. \\
\hline
\end{tabular}

Bogfottegutelie til Beifeduing for Sognebibtiotheler.

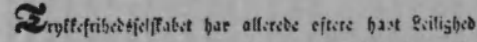

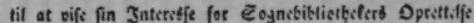
os Jier ez enfir frimbilis at funne sirfe til Bopite for

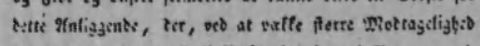
fer foub oct foritayes til Jolfieply!ningens Frimme, reo

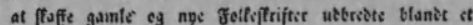

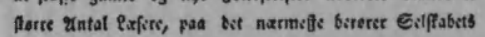
Znteretfer. 3 Betragtning af ie Banfteligbiest, bic mase antagib at sare forbunone med et binfigtsmatijat Balg

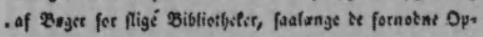

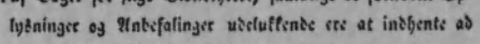

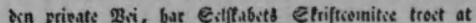
burbe binesnbe fin Opmarffombio pas sinne Tod af Eagen. Din onffece sirfor at tilscistringe en Jortiga nilfe ewr fantanne af sor Sittsraturs Efrifter, tis sio

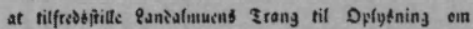
2Renniffits ellit Etatsborgetens afminsifige oy Bonsins

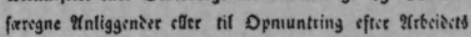
Dreifonmatigbsicte, maatte fortione fortrinseiis at antis fatis Eegnebibliotgsterne til भinffaffilfe. I Jortegniffon

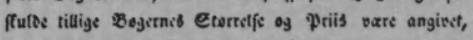

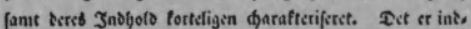

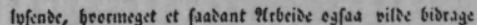
tit at paavife Easn not vor folfesige eittsratur, fom sllers $i$ lang sib funie blies ubemarfios. Don is bis

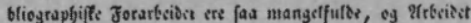

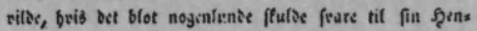
figt, ustrave fas omfattinde sijniplas til simue liset pasagtide Bresn af ror alore og nyere gittiratur, faa for Fortreligbio unco Iffuuins emay og fas affisiy Opmats formber paa bens fornoocnfeber, at out, foum Eagerne toe Xatgang. nu flase, iffe ril fuane escibrayis ril Enfittmano, at forfatte in Jort:yac if fein din cesnfor b.jfessas.

For altjas reb Jliris Eambirfin at fase ulrittit,

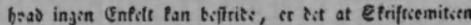
tildaser fig at uejtose in alminislis Deffertring til be Mand i sllet utenfor Esclpabet, sit attin net at anfitide

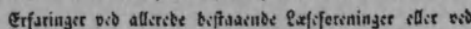

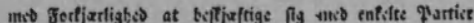

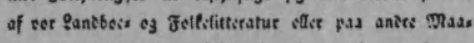

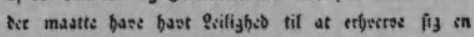

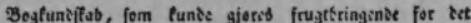

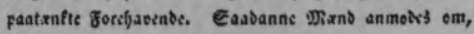

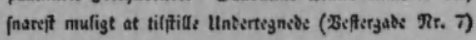
en Dpitift af Titferne paa de Boger, se tree, farbisis at Punne anbifale tir Bruy for Eognebiblistbiter, fant o:n

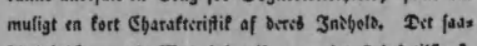

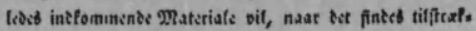

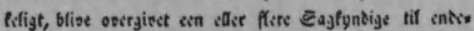

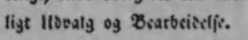

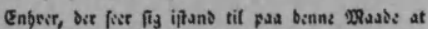

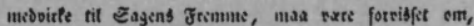
at Man vil paaftionne bans forre ctlist mintere Bisrag, ved famvittigbectefulot at benytte dem.

siobentaen b. It mai 1811.

Yas Efriftcomitount Vignẹ g. wa alter,

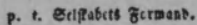

\section{Den bante Straffelobgibning.} (glutning).

23i gave fert, boilfe ie fornemife etraffimadict bare i

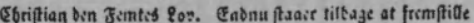
Grunotraffene $i$ detes ubsilfing gjennem is folginde sis (10,11) 
§2: Ved Belønninger søger Selskabet at fremkalde gode og nyttige Skrifter, skikkede til i alle Borgerklasser at forædle Sindet, forbedre Smagen og udbrede Kundskaber, fornemmeligen om Kommunalvæsen, Handel og andre Næringsveje, samt hvad der overhovedet griber ind i Borgerlivet. Saadanne Prisskrifter saavelsom andre Bøger, tjenlige til samme Øjemed, foranstalter Selskabet udgivne og udbredte i Folket. " ${ }^{6}$

Ud over de næunte skrifter var medierne for denne folkeoplysning Selskabets tidsskrift Dansk Folkeblad og støtte til biblioteker, især gennem gratis uddeling af Selskabets udgivelser. Udgivelserne blev forestået af en skriftkomité på 9 medlemmer.

Som det ses af formålet henvender Selskabet sin oplysning til "alle Borgerklasser", til hele folket. I sidste instans er det dog i høj grad by- og landalmuen, der, bredt forstået, er genstand for oplysningen. Både Dansk Folkeblad og Selskabets bøger formidler stof på flere niveauer, til flere målgrupper end almuen.

Som det fremgår af $\$ 2$ er oplysningen kombineret med dannelse; områderne for oplysning og dannelse kan skematiseres således:

- moralsk dannelse ("at forædle Sindet «), der kan forstås i lyset af den kristeligt-rationalistiske tradition;

- æstetisk dannelse ("at forbedre Smagen"), der kan ses i sammenhæng med - groft sagt - Biedermeierkulturen;

- statsborgerlig oplysning (»Kommunalvæsen «/»Borgerlivet «);

- erhvervsmæssig eller samfundsborgerlig oplysning ("Handel og andre Næringsveje ").

Mht. den erhvervsmæssige oplysning er det værd at mærke sig, at handel er det eneste, der nævnes specifikt, hvilket lader ane, at det, jf. den store gruppe af grosserere, købmænd og detailhandlende, er handelskapitalen, der tillægges det økonomiske potentiale. (Fysiokratismen er et overstået stadium).

Som tidligere næunt fầr Dansk Folkeblad i 1843/44 en mere markant og mere offensiv politisk karakter. Bladet bliver på dette tidspunkt orienteret mod aktuelle politiske forhold med hovedvægt på, 
hvad der sker i provinsialstænderne. Beslaglæggelsen af bladet selv behandles også. Andre temaer er censurens opkomst og udbredelse, nationalitet og nationale bevægelser, statsregnskaber, kornpriser, slaveriet, husmændenes kår, dårevæsnet og undertrykkelsen af bøndernes forsamlingsfrihed (i 1845). Denne politisk-økonomiske og aktuelle orientering i stoffet står i ret markant modsætning til årgangene op til 1843, hvor oplysningsfeltet er bredere, politisk mere neutralt, i højere grad historisk orienteret, samt præget af den filantropiske tradition og en tro på den rolige udvikling og $\mathrm{i}$ det hele på udvikling.

På det politiske område er artiklerne mere oplysende end diskuterende. Læserne oplyses om landets finansielle forfatning, om penge og møntvæsen, om veksler, om retspleje, om skattevæsen, om undervisningsvæsen og en række andre statsborgerlige anliggender.

De historiske og kulturhistoriske artikler behandler på den ene side udviklingen på en række specielle områder og på den anden side vigtige begivenheder og personer i den nationale historie. Mht. udviklingen drejer det sig f.eks. om vaccine, jernbanen, dampmaskinen og industri inden for det medicinsk-teknologiske område og om forbedringen af bøndernes kår, socialfilantropiske foranstaltninger, forsamlingsfriheden, laugsvæsnet, samt censur-og presseforhold på det samfundsmæssige og politiske område.

For den nationale histories vedkommende er det krige mod tyskerne og svenskerne, der er i fokus. Niels Ebbesen kæmpede mod tyske herrer og herremandsprivilegier, han var med til at sætte det danske folk $\mathrm{i}$ bevægelse $\mathrm{i}$ en stræben af national art. Oprør fra svundne tiders bonde- og borgerstand fremstilles som udtryk for en retfærdig stræben $i$ lighed med bornholmernes opstand mod svenskerne i midten af 1600-tallet. Blandt andet i disse historiske artikler findes de mere afdæmpede politiske signaler.

Det nationale og den nationale kultur spiller også en rolle, både dannelseskulturen og folkets kultur. Stoffet om den nationale dannelseskultur er imidlertid ret begrænset; her er Thorvaldsen, Oehlenschläger og Ingemann centrale personer. På den folkelige, nationale kulturs område tages f.eks. folkemusikken op under synspunk- 
tet, at den må reddes af de dannede, da vore "gamle nationale klangfulde Viser " ellers vil forsvinde. Den folkelige litteratur behandles i forbindelse med Olger Danskes Krønike.

Ud over de nævnte områder er der stof om religiøse forhold. Det er overvejende aktuelt orienteret og har statskirkelige emner som det centrale. Et emne, der blev behandlet i 1839, var biskop Mynsters Udkast til en Kirkebog og et Alterritual for Danmark. H. N. Clausens Betragtninger over Ritual-Sagen kritiserer på den ene side, at behandlingen af Mynsters udkast er blevet holdt inden for en snæver gejstlig offentlighed, på den anden side tilslutter han sig fornyelsen og de "gudstjenstlige Forbedringer". H. N. Clausens argumenter for denne tilslutning er, (1) at der sker en udvikling på alle områder, også inden for kirken, (2) at den eksisterende forordning, der er forældet, har fremmet "en bitter, hadefuld Partistrid " og dermed svækket statskirken, og (3) at det nye udkast vil - med frihed, men uden vilkårlighed - give den nødvendige enhed i gudstjenesten. Nødvendig fordi gudstjenesten er den statskirkelige læres synlige udtryk. H. N. Clausens artikel er karakteristisk ved at forsvare den offentlige diskussion af statskirkelige anliggender og ved at forsvare en vis, "naturlig " fornyelse inden for statskirken. Andre religionsemner var bl.a. »de fremmede Religionsbekjenderes borgerlige Stilling i Danmark " og salmer. I artiklerne om andre religioner lægges der også megen vægt på statskirkens forhold til disse.

Mellem 1839 og 1843 kommer oplysningen i stigende grad til at rette sig mod bønderne, og i nogen grad kommer den også til at handle om husmændene. Almuens mistillid til de dannede klasser bliver et tema. Denne mistillid eksisterer "Uanseet det Meget, de højere Classer nu virke for Almuen «. Denne forestilling om de dannede klassers uegennyttige virke for almuen, for børn af hovedstadens almueklasse, "som staae i Fare for at tabes for Samfundet " og $\mathrm{i}$ det hele taget for folket er naturligvis gennemgående $\mathrm{i}$ disse årgange af Dansk Folkeblad, i overensstemmelse med borgerskabets forståelse af egne interesser som "Almeeninteresserne" .

I 1841/42 behandles kvindens oplysning, og der dukker en kvindebiografi op (Elisabeth Fry), der sætter et kvindeideal om opofrelse ind mellem alle mønstereksemplerne på mænd, der ved talent og 
virkelyst, "uden Formue, i Kamp mod allehaande Hindringer, kan skaffe sig Dannelse og Dygtighed og skabe (...) egen Lykke«.

På kunstens område tager Dansk Folkeblad omkring 1840 sig nærmest ud som eksponent for en 'enevældeoffentlighed'. Der er sørgedigte og mindesange i forbindelse med Frederik den Sjettes død, bl.a. et skrevet af Ingemann og et med melodi af A. P. Berggreen. J. M. Thiele besynger Christian den Ottendes tronbestigelse, og i et andet digt til samme hedder det håbefuldt: "Og du vil modne Folkeraadets Høst «.

Et andet stofområde er anmeldelser af bøger som "er passende til almeen Læsning " og som er billige. Flere af Ingemanns historiske romaner er anmeldt anonymt i kort form. Om tredie oplag af Waldemar Seier (1841) skrives der efter omtalen af den lave pris:

"Hensigten er, at Mange skulle kunne kjøbe og læse denne Bog. Da det er en Roman, er det Meste, som staaer deri, opdigtet, men knytter sig dog til Begivenheder og Personer, hvorom Historien og vore gamle Kjæmpeviser melde; og Digteren har af Skrifter og paa anden Maade samlet, hvad der kunde give Læseren Begreb om de gamle Tiders Skik og Tænkemaade, saa man har her nogenledes Leilighed til at gjøre ligesom en Reise til den henfarne Slægt, I Waldemar Seiers Dage. Naar Bogen kjøbes til Laanebogsamlinger paa Landet, vil den finde flittige Læsere, og Pengene saaledes ikke være forgjæves udgivne. ${ }^{7}$

Man kan bemærke, at anmeldelsen bl.a. er rettet mod dem, der køber ind til lånebogsamlinger, og at den her har et fornuftigt økonomisk synspunkt på indkøbet.

Dansk Folkeblad i tidsrummet 1839-43 er i høj grad udtryk for de samme oplysningsbestræbelser som Marckmanns fortegnelse.

Folkeoplysning og biblioteker

I Trykkefrihedsselskabet blev biblioteker anset for at være nødvendige, for at oplysningsarbejdet kunne lykkes. Der var grænser for, hvor langt Dansk Folkeblad nåede ud i folket, og der var fă eksisterende almuebogsamlinger at bygge på. Derfor fik oprettelse af 
biblioteker, støtte til biblioteker og formidling af litteratur $\mathrm{i}$ forbindelse med biblioteker en ret høj prioritet. ${ }^{8}$

Ud over den optimistiske tro på oplysningens nytte var Selskabets oplysningsarbejde også begrundet $\mathrm{i}$ forhold til andre politiske og kulturelle fronter. Den ene front var "en Classe" af politiske blade, der "gik for vidt «. Den anden front var en fordærvelig litteratur. Om det første skriver "s.n. « i Dansk Folkeblad i 1836:

"Den Classe af Blade, som baade ved Indhold og Form nærmest er fattelig for Landalmuen, er naturligvis den, som allermindst bør komme i dens Hænder, - vi mene den Syndflod af Styverfængeriets elendige Fostre, som i disse sidste Aar have oversvømmet Hovedstaden. Saadanne Blade underrette sædvanligviis Publikum om, at deres Formaal er at værne om »Retfærd og Moralitet «, eller, almindeligere udtrykt, "at fremme Statens Vel". Men under denne skinhellige Maske er deres fornemste Gjerning den, at gjøre Skamløse Udfald mod Næstens gode Navn. «"

Trykkefrihedsselskabets kamp mod den usædelige litteratur var rettet mod lejebibliotekerne og $\mathrm{i}$ et tilfælde mod en bogtrykker, som Selskabet ville forhindre $\mathrm{i}$ at udgive Paul de Kochs Hanrejen. ${ }^{10}$ Denne bog er et udpræget eksempel på den litteratur, der blev betragtet som usædelig.

I forhold til rationalismens oplysningsbestræbelser er det værd at mærke sig, at fronterne er nye. Den rationalistiske oplysning stod ikke over for nogen alternativ politisk oplysning, og på litteraturområdet var det folkebøgerne, der var en trussel mod moralen.

Den ovenfor citerede "s.n." har i samme artikel (med titlen Om Laseforeninger blandt Landalmuen) en række overvejelser, der fokuserer på, hvad der skal udvælges af "Læsegjenstande" til landalmuen, og hvordan disse skal formidles.

I overensstemmelse med Selskabets politik går "s.n." naturligvis ind for biblioteker/læseforeninger. På det politiske område sætter han et skarpt skel mellem, hvad der er egnet for den dannede statsborger, og hvad der er egnet for bondestanden, hvis indsigter $i$ 
statsanliggender »ere saa højest mangelfulde og tidt grundforkeerte«:

"Men man huske paa, at, hvad den Dannede læser ikke alene uden Skade men til Nytte, det kan den mindre Dannede læse ikke alene uden Nytte men til Skade. " ${ }^{9}$

Det, det drejer sig om, er de forskellige politiske anskuelser, som diskuteres i den borgerlige offentlighed. Den politiske offentlighed er ikke umiddelbart et sted for bondestanden, dels fordi det ikke er meningen, at bondestanden skal "tælle ret mange politiske Kandestøbere i sin Midte", dels fordi den politiske meningsudveksling vil bringe forvirring og misforståelse for den politisk udannede bonde.

Artiklens forfatter laver altså en klar markeringslinie mellem den dannede statsborger og den udannede bonde på det politiske område. I forbindelse hermed stiller han så spørgsmålet om oplysningens relevans for bondestanden. Er den i det hele taget relevant, når den politiske oplysning er udgrænset?

På dette retoriske spørgsmål svarer "s.n. "selvfølgelig ja. Selv om bonden ikke kan gå lige ind i den politiske offentlighed, er der meget at oplyse ham om. Men enhver oplysning af bondestanden kræver et omhyggeligt valg af: "Læsegjenstandene " og "en middelbar Vejledning, til at forstaa og dømme om det Læste«. Til begge dele kræves der dannede mænd. Marckmanns Fortegnelse over Skrifter til Lasning for Menigmand, der udkom i 1844, 8 år senere, blev et vigtigt redskab til udvælgelse af "Læsegjenstandene" og også en hjælp til "middelbar Vejledning ", idet annotationerne var rettet mod de dannede borgere, præster og lærere især, der stod for sognebibliotekerne.

\section{J. W. Marckmann og folkeoplysningen}

Jørgen Wilhelm Marckmann (1804-61) kom fra en embedsmandsfamilie (faren blev by- og herredsskriver) og blev selv præst, lærer på Borgerdydsskolen, aktivt medlem af Trykkefrihedsselskabet og 


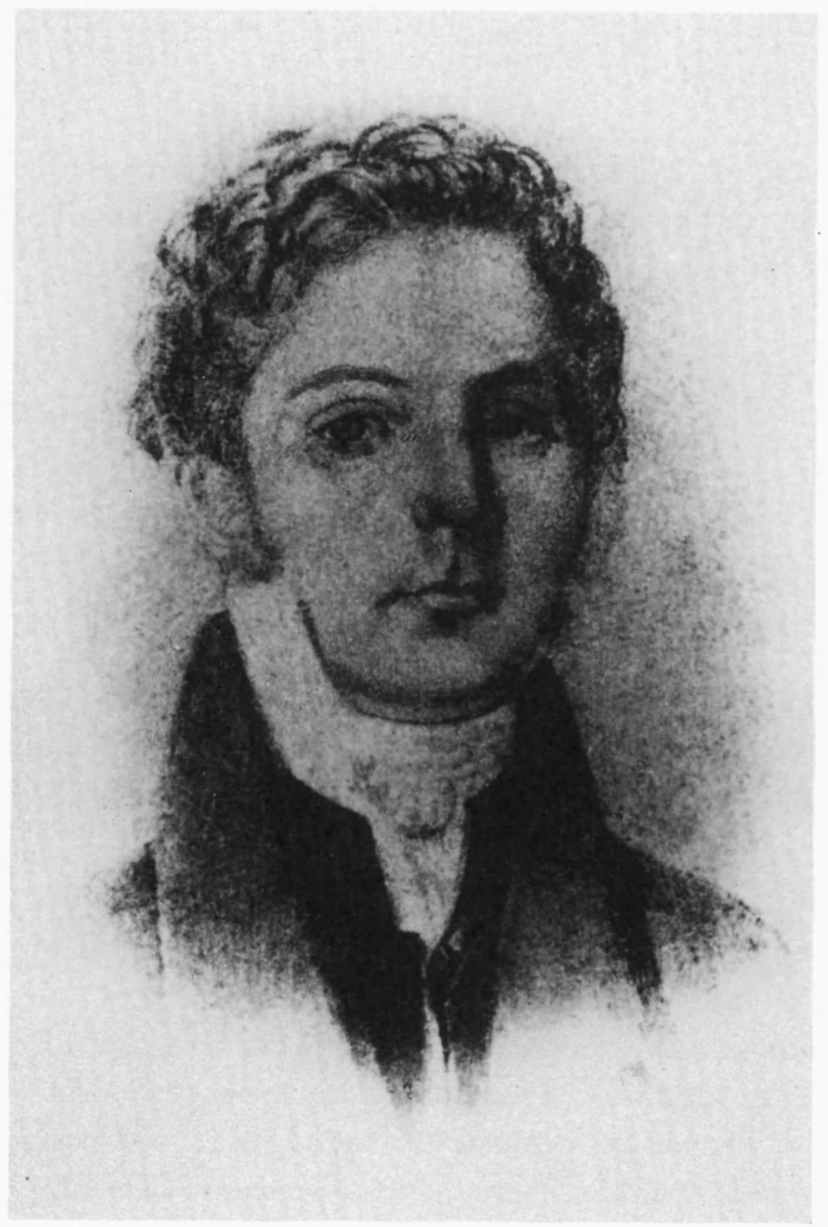

J. W. Marckmann, 1804-61. Folkeoplyser og medlem af Trykkefrihedsselskabet. Det kgl. Bibliotek, Billedsamlingen.

senere medlem af den grundlovgivende rigsdag og folketinget. ${ }^{11}$ Han var således repræsentant for den lavere del af den københavnske embedsmandsstand, da han var aktiv i Trykkefrihedsselskabet. Han flyttede fra København i 1849.

Marckmann skrev om "Menigmands Oplysning " i Dansk Folkeblad, han forfattede bogen om "Franklins Levnet ", som Trykkefrihedsselskabet udgav i 1837 og igen i andet oplag i 1839, og han lavede med Fortegnelse over Skrifter ... i 1844 landets første, egentlige annoterede litteraturliste. (P. F. Suhms Nødvendigt Bibliotek må karakteriseres som et bibliografisk essay). 
I 1839 skriver Marckmann i en artikel Om Menigmands Oplysning under pseudonym: Olbe, Kammerraad. Til dette pseudonym knytter han en fiktiv identitet. Artiklens jeg er en gammel kammerråd, der ser de aktuelle oplysningsbestræbelser $i$ lyset af sin ungdoms "erfaringer «:

"Min modnere Ungdom indtraf den Tid, da Bondesagen satte alle Hjerter i Bevægelse, og som Medlem af Drejers Klub har jeg levet med Wadum og Storm og flere af de Mænd, hvis varme Deeltagelse for hiin herlige Sag endnu ikke er glemt af den yngre Slægt. «12

Med denne fiktive tilknytning til Drejers Klub, der startede i 1775 , placerer Marckmann Trykkefrihedsselskabets aktuelle oplysningsbestræbelser i en tradition. Drejers Klub var forum for diskussion af og tilslutning til liberal økonomi, landboreformer, oplysning og trykkefrihed. Den fiktive kammerråd, der siden sin ungdom er kommet $\mathrm{i}$ berøring med folket, kan meddele læseren sin glæde over den nye tids oplysning:

"De vil altsaa kunne forestille Dem, hvor det har glædet mig, at denne nye Tid igjen har foretaget en Sag, som har været min Ungdoms Glæde, og atter begyndt at virke for Folkets Oplysning. «" ${ }^{12}$

I artiklen indbygger Marckmann endvidere en godsejers absolutte afvisning af folkeoplysning ud fra gamle argumenter om, at den oplyste bonde ikke vil blive ved sin plov eller ikke vil gøre sit kedsommelige arbejde. Kammerråden fik ikke svaret godsejeren, inden denne gik; hvilket begrunder at han er nødt til at give sit svar skriftligt. Med denne fiktive ramme og med argumenterne for menigmands oplysning kommer Marckmann forst og fremmest til at stå som eksponent for oplysningstidens rationalisme:

"Når jeg siger, at den almene Mand burde erholde større Dannelse, kan jeg naturligviis ikke mene, at han skulde blive lærd eller saaledes fortabe sig i Speculeren og Læsen, at han glemte sin Stilling eller forsømte dens Pligter; men jeg mener, at han kunne erholde mere 
Kundskab om Verden og Livet og fornemmelig om sit Fødeland, sin Stand og sin Gjerning, om sin Ret og sine Pligter, saa at han fik et klarere Begreb og bedre Sans og Sind. « ${ }^{12}$

Argumentationen fortsæetter med, at den "cultiverede, almene Mand " fầr udviklet sin pligtfølelse med det resultat, at der bliver færre "Mennesker for Fattigvæsenet at føde». Og:

"Endelig maa jeg gjøre en Bemærkning, som synes mig meget vigtig; det er den, at jo mere indsigtsfuld en Mand er, desto mere Forstand lægger han i sit Arbeide; Landmanden gjør Iagttagelser, indfører Forbedringer, anstiller Forsøg; Haandværkeren stræber at gjøre sit Arbeide fuldkomnere, søger saa vidt muligt at forædle det til Kunst, og hermed faar den Gjerning, som for den Raae og Udannede er tankeløs og maskinmæssig, en heel anden Interesse. (...)

Jeg bliver ved min gamle Mening og troer ydermere, at der for vort Fædreland for nærværende Tid intet er vigtigere end Folkets Dannelse. (...) «13

Som det er formuleret her, er det pligtfølelse (internaliseret moral), forbedring af arbejdet og fædrelandets ve og vel, der er formålet med folkets oplysning. I en artikel i Kjøbenhavnsposten, optrykt i Almuevennen, ${ }^{14}$ har kammerråd Olbe fremsat sit syn på Det politiske Røre i Folket. Denne artikel, der skelner stærkt mellem situationen i Frankrig og i Danmark, indeholder trods den i 1840 udbredte frygt for at 1839-revolten i Frankrig skulle brede sig til Danmark, et forsvar for det "Liv«, der er kommet i folket. Ifølge Marckmann er årsagen til de revolutionære opstande i Frankrig de franske kongers undertrykkelse afffolket. I Danmark derimod har Frederik den Sjette forbedret folkets vilkår. Blandt andet derfor behøver man ikke frygte

"(...) en reen Sodomas og Gomoras Forstyrrelse og Jerusalems Ødelæggelse, dersom Stænderne fik nogen egentlig Magt. « ${ }^{15}$ 
Hvad der endvidere, implicit, må spille en vigtig rolle her, er folkets dannelse. Citatet ovenfor om betydningen af folkets dannelse for fædrelandet "for nærværende Tid " kan tolkes ind i denne politiskhistoriske kontekst: en side af formålet med folkeoplysningen, med folkets dannelse, var også for Marckmann at undgå franske tilstande.

Omtrent samtidig med, at Marckmann offentliggjorde artiklen Om Menigmands Oplysning, blev han medlem af en komité »til drøftelse af de midler, der bør anvendes til at understøtte og fremkalde læseindretninger for almuen. " ${ }^{16} \mathrm{Udvalget}$ havde en betænkning færdig i september 1839 (men den blev først behandlet mere end 1 år senere). Komitéen indstillede 6 punkter, blandt andre:

- „Udgivelse af et Skrift, hvori Nytten af Almuebibliotheker vises. « - "Nedsættelse af en Comité, der skulle have Tilsyn med Almuebibliothekerne. "

- »Nedsættelse af en Comité, der skulle lede Valget af Bøger for Almuebibliothekerne. «17

Ingen af disse 3 punkter blev vedtaget i Trykkefrihedsselskabet. Men punkterne er udtryk for den tidligere omtalte tro på almuebibliotekernes nytte og for understregningen af, at der må dannede mænd til at lede valget af "Læsegjenstande" til almuen og til at stå for formidlingen af disse "Læsegjenstande" .

Marckmanns fortegnelse kan også ses i forlængelse af disse konkrete bestræbelser. Den 28. maj 1841 indrykkede skriftkomitéen en opfordring om indsendelse af litteraturlister over bøger egnede til almuelæsning,

»en Fortegnelse over saadanne af vor Litteraturs Skrifter, der ved at tilfredsstille Landalmuens Trang til Oplysning om Menneskets eller Statsborgerens almindelige og Bondens særegne Anliggender eller til Opmuntring efter Arbeidets Møisommeligheder, maatte fortjene fortrinsviis at anbefales Sognebibliothekerne til Anskaffelse. «" ${ }^{18}$ 
I overensstemmelse med Trykkefrihedsselskabets formål er områderne for oplysning formuleret ud fra "opdelingen af borgeren " $i$ menneske (moral, æstetik), statsborger og samfundsborger.

Marckmanns "Fortegnelse over Skrifter til Lasning for Menigmand" I referatet fra Trykkefrihedsselskabets bestyrelsesmøde den 15 . marts 1842 anføres følgende:

"Til at afgive Betænkning angaaende en Fortegnelse over saadanne Skrifter i vor Litteratur, der fortrinligen egne sig til Almuelæsning, - hvilken Fortegnelse med det Første kan ventes færdig fra Pastor Marckmanns Haand, besluttedes det at nedsætte en Comite af 5 Medlemmer, hvortil derefter med Stemmeflerhed valgtes: Cammerraad Drewsen (med 14 Stemmer), Bibliothekssekretær Fabricius (med 13), Overlærer Olsen (med 11), Pastor Børresen (med 10) og Professor P. Hjort (med 9). «19

Marckmann har altså på et tidligere tidspunkt fầet overdraget opgaven.

I referatet fra Repræsentantforsamlingen den 29. april samme år står der:

„For at give Almuebibliothekerne en Veiledning i Valget af de Bøger, der anskaffes, er en Fortegnelse over Skrifter, der ere meest skikkede til Almuelæsning, ifølge Skriftcomiteens Opfordring bleven udarbeidet og circulerer fortiden hos en til dens Bedømmelse nedsat Comitee. Den kan i indeværende Aar ventes omdeelt og vil forhaabentlig blive en velkommen Gave for Læseforeningerne. «"

Det var helt i overensstemmelse med Trykkefrihedsselskabets praksis, at der blev nedsat en bedømmelseskomité for hver enkelt bog, som Selskabet overvejede at udgive. Men at bogen, trods optimismen vedrørende dens udgivelse i 1842, først udkommer i 1844, er et særsyn, der lader ane, at det ikke har været helt let at opnå enighed i komitéen.

Trykkefrihedsselskabets forhandlingsprotokol vender først til- 


\section{fonteguelfe}

ober

\section{Skrifter til farsning for atenigmand,}

fornemmelig til Brug for Befturere af Sognebibliothefer, meo et 2rnbang om Sognebibliotbeter,

af

3. พอ. Marckmann.

Uugivet af Selfęabet for Irruffefribebens rette \$Brug.

Briis cyeralt $i$ Danmarf 36 @f. heftet.

fijobenbayn.

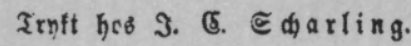

1844. 
bage til sagen i referatet fra bestyrelsesmødet den 3. april 1844. I referatet står der følgende om punktet:

"3. Ifølge den i sin Tid nedsatte Comites Anbefaling, blev den af Pastor Marckmann forfattede "Fortegnelse over Almueskrifter ", saaledes som den nu var bleven omarbeidet, antagen til Udgivelse ved Selskabet.

Det sattes under Quæstion, om dette Skrift, ligesom de andre ved Selskabet udgivne Bøger, skulde omdeles til alle Medlemmerne, da det antoges kun at ville interessere Enkelte iblandt disse. Det [fandtes?] imidlertid efter Lovene at være nødvendigt, ogsaa i dette Tilfælde at følge den sædvanlige Fremgangsmaade. Om hvorvidt der kunde være Anledning til, saaledes som det endvidere blev foreslaaet, at omsende Skriftet ikke blot til de Sogne, der havde Friexemplarer af Selskabets Skrifter, men ogsaa til Landets øvrige Sogne, udsattes det at tage nogen Bestemmelse, indtil Skriftet var udkommet.

Oplagets Størrelse bestemtes til 5500 Expl. Forfatterhonoraret blev på Grund af den særdeles Møisommelighed, hvormed Udarbeidelsen af dette Skrift havde været forbundet, fastsat til $40 \mathrm{Rbd}$. for Arket, eller det dobbelte af det sædvanlige Honorar. ${ }^{21}$

Forhandlingsprotokollen nævner af gode grunde ikke noget om omarbejdelsen (der ikke var et bestyrelsesanliggende). Vi havde håbet at finde noget i Marckmanns korrespondance, der fortalte om udarbejdelsen og omarbejdelsen, men fandt desværre intet, der kunne belyse udvælgelsen og forholdet mellem Marckmanns arbejde og komitéens reaktioner.

Angående spørgsmålet om rundsendelse af skriftet til alle sogne blev resultatet, at

"I april 1846 sendes en del eksemplarer af bogen til bisperne med anmodning om, at de vil foretage en uddeling blandt stifternes præster. I følgeskrivelsen oplyses, at man ønsker fortegnelsen uddelt blandt præster i de sogne, der endnu ikke har noget bibliotek, da 
målet er oprettelse af et bibliotek i hvert pastorat. Men dermed var selskabets arbejde for oprettelse af biblioteker afsluttet, (...). ${ }^{22}$

Marckmann indleder sin fortegnelse med en "Forerindring ", hvor han redegør for fortegnelsens sigte, karakter og for de overvejelser, han har gjort sig mht. udvælgelsen og annoteringen af de 431 titler fortegnelsen omfatter.

Han tager sit udgangspunkt i et optimistisk syn på folkebibliotekerne, der antages, at "blive af megen Betydning for Folkeudviklingen i vort Fædreland «. Fortegnelsen skal løse problemet med, at bestyrelserne for folkebibliotekerne »ikke kunde have tilstrækkeligt Kjendskab til de Bøger i vor Litteratur, som ere hensigtsmæssige til Læsning for Folket«. Han redegør endvidere for, at det, trods bistand fra kyndige mænd, er hans værk, og at det er »et første Forsøg i sin Art ". Han henviser til Collins fortegnelse, der i 1807 blev udgivet af Landhusholdningsselskabet; men bl.a. grundet dens manglende annotationer har den ikke kunnet tages som mønster.

Om målgruppen (i sidste instans) skriver Marckmann:

"Ved Affattelsen af denne Fortegnelse har jeg nærmest havt Bondestanden for $\varnothing$ ie som den, der især har Trang til Læseanstalter. Men Bondestanden staaer paa et forskjelligt Trin af Dannelse baade i dens forskjellige Afdelinger (Selveiere, Fæstebønder, Huusmænd) og i de forskiellige Egne; derfor maatte der ogsaa i denne Fortegnelse optages Bøger, der svare til et noget forskjelligt Culturtrin. «"23

Børn var ikke med i Marckmanns målgruppe. Af H. C. Andersen er således kun medtaget Nye Eventyr [1. hæfte] 1844. Ikke de 6 hæfter Eventyr, fortalte for Born (1835-41). Der er i det hele taget ikke medtaget nogen egentlig børnebog. Når Den danske Børneven, P. Hjorts Læsebog for Borger- og Almueskoler er medtaget (nr. 263), er det med den begrundelse, at den vil være at anbefale til læsning for den voxne. Tilsvarende om Raffs Naturhistorie for Born (nr. 55) m.fl. Helt tydeligt bliver dette, når man ser, at der af Campes Robinson den Yngre udtrykkeligt er medtaget en udgave, som "gjør Indholdet 
mere passende for Voxne blandt Folket, da Børnesamtalerne ere udeladte" (nr. 328). ${ }^{24}$

Landalmuens forskellige kulturtrin er begrundelsen for, at fortegnelsen indeholder så mange titler; fortegnelsens udvalg skal kunne dække alle landalmuens læsebehov. På grundlag af annotationerne ("de veiledende Meddelelser") skal "Læseanstalternes Bestyrere (sættes) istand til selv at udsøge de Bøger, som svare til de forskjellige Steders Fornødenhed «. Marckmann har endvidere indbygget en yderligere vejledning ved typografisk at fremhæve de titler, der kan danne grundbestand for et almindeligt sognebibliotek.

Marckmann har en række overvejelser over, hvad der gør litteratur passende for "Menigmand «. Skrifterne må ikke stå over menigmands sfære, de behøver ikke nødvendigvis være skrevet for menigmand, men "Alle gode Skrifter (...) har jeg meent at kunne anbefale (...) naar de omhandlede folkelige Emner og med Hensyn til Fremstilling og Sprog vare fattelige, samt ikke udkrævede formange Forkundskaber «. ${ }^{25}$

Marckmann har, i overensstemmelse med Trykkefrihedsselskabets formål, valgt bøger, der ligger ud over den tidligere rationalistiske oplysningstraditions moral- og nyttetænkning, og som retter sig mod den æstetiske dannelse:

"At jeg i Fortegnelsen ikke blot har optaget saakaldte nyttige Bøger, men ogsaa saadanne, som med et populært Udtryk benævnes Morskabsbøger, eller med andre Ord, at jeg har meent, man ikke alene skal stræbe at forøge Menigmands Kundskab, opklare hans Begreber og befordre hans Selvtænkning, men ogsaa ved Indflydelsen af det Æstetiske søge at vække hans Aand og danne hans Smag, behøver neppe noget Forsvar. $\aleph^{25}$

Marckmanns litteraturudvalg omfatter, som emneopdelingen viser, et ret bredt univers for oplysning, kundskab og dannelse: 
Religiøse og moralske Skrifter................. 47

Skrifter, som meddele Kundskab om Naturen ..... . . . . . 12

Skrifter, som beskrive Folkeslag, Lande, Egne og Stæder.... 61

Historiske og statistiske Skrifter ................. 66

Skrifter, som meddele Oplysning og Veiledning med Hensyn

til borgerlige, huuslige, oeconomiske og techniske Forhold 76

Skrifter til almindelig Dannelse og Underholdning . . . . . . 136

Landkort ............................ 9

Musicalier .............................. 13

(Tillæg ..............................

I alt 431

I det følgende vil vi kommentere udvalget og annoteringerne i nogle af fortegnelsens emnegrupper.

Religiøse og moralske Skrifter

Det er naturligt et stort afsnit, på i alt $47+4$ numre. Afsnittet begynder med forklaringer til Det nye Testamente, dernæst prædikensamlinger, videre almenkristelige opbyggelige bøger (nr. 11-31), salmer (nr. 32-38) og sædelærer (nr. 39-47). Herunder Mallings Store og gode Handlinger. Der er også religiøse og moralske skrifter andre steder i Fortegnelsen. Der er således en halv snes kirkehistoriske bøger med i afsnittet "Historiske og statistiske Skrifter ", og der er moraliserende skrifter med i hvert eneste afsnit.

Marckmann har naturligvis ikke Det nye Testamente, Salmebogen eller "Lærebogen" (Katekismen), for dem har almuen selv haft på dette tidspunkt. Den autoriserede bibeloversættelse blev udbredt til folket efter 1814, hvor det Danske Bibelselskab blev stiftet. ${ }^{26}$ Men Marckmann kunne have medtaget Lindbergs oversættelse (1837ff), der af Skautrup karakteriseres således: "I denne oversættelse, der var tilegnet Grundtvig, (...) gav Lindberg det danske folk en virkelig folkebibel, skrevet i et djærvt og levende dansk ... «. ${ }^{27}$ Der kan være to gode grunde til, at Lindbergs oversættelse ikke er med. Den ene, at Lindberg er grundtvigianer, den anden, at oversættelsen, ved nogle smagløsheder og stilbrud, stødte an mod god smag. Det var to grove fejl! 
Afsnittet indledes med evangeliske forklaringer; men der er ingen udgaver eller forklaringer til Det gamle Testamente. Kun Jobs Bog nævnes en passant i noten til nr. 42. Der var megen betænkelighed blandt de rationalistiske præster ved at lade almuen fầ Det gamle Testamente i uforkortet skikkelse. Kong Frederik den Sjette ville således ikke tillade et officielt revisionsarbejde af GT (en naturlig fortsættelse af revisionen af Nye Testamente 1819), udtrykkeligt, fordi han havde uvilje mod, at GT skulle udbredes blandt almuen. ${ }^{28}$ Jobs bog indtog dog en særstilling. Og der var blandt næsten alle præster betænkeligheder ved at lade almuen fầ indblik i skrifter der kunne røbe teologernes indbyrdes uenigheder.

Der er 7 numre salmesamlinger, indledet af P. Hjorts Gamle og nye Psalmer. 3. udg. 1843 (nr. 32). Denne udgave rummer næsten 400 salmer. "Samlingen er upaatvivlelig, saavel i poetisk som religiøs Henseende, den bedste, vor Litteratur besidder, og fortjener desaarsag fortrinlig at anbefales. " Noten nævner desuden: „De ældre Psalmer ere heldigen rensede fra forældede og feilfulde Udtryk og Billeder. "Dette er uden tvivl et hib til den autoriserede Evangelisk-Kristelig Psalmebog (1798) i hvilken de gamle salmer var blevet omskrevet i fad rationalistisk ånd. Astetikeren Hjort havde ført dem tilbage til deres gamle kernefulde skikkelse. Flere af de medtagne salmesamlinger har Grundtvig-salmer med - Hjort ikke mindre end 48 - men det er alligevel påfaldende, at der ikke er medtaget en særskilt grundtvigsk samling: Sang-Vark til den Danske Kirke (1. bd., 1837) eller f.eks. Lindbergs Rosen-Kjaden (1843), der hovedsagelig rummede Grundtvig-salmer. Brorson og Ingemann er således repræsenteret med særskilte salmesamlinger.

Langt den største del af det religiøse afsnit udgøres af prædikener og opbyggelsesbøger (27 nr.). Det indledes fornemt med Mynsters prædikener, og senere følger yderligere hans Betragtninger over de christelige Troeslaerdomme. Af Mynster er der således medtaget alle de tre værker, som overhovedet kunne komme på tale indtil 1844, i alt ca. 2300 sider. Det forekommer urimeligt $\mathrm{i}$ en fortegnelse beregnet for sognebiblioteker. Vi vil naturligvis ikke forklejne disse prædikeners betydning for den danske (fin)kultur, men vi tvivler på at almuen har kunnet goutere deres højlitterære skriftprosa. Marckmann 
skriver selv, at "Menigmand ikke forstaar Alt i disse classiske Skrifter". Overrepræsentationen af Mynsters værker kan efter vores mening ikke kun forklares med, at man "høiligen tiltales af deres Aand « (nr. 6), men må tilskrives den absolutte eneherskerstilling, Mynster indtog i Kirken.

Så meget des mere falder det derfor i øjnene, at Grundtvig ikke er repræsenteret ved nogen prædikener. Der kunne især have været tale om Christelige Pradikener eller Sondags-Bog, 3 bd. (1827-30). "Kun meget faa - om overhovedet nogen - danske Prædikensamlinger [er saa] læseværdige som denne ... « ${ }^{29}$ Der er heller ingen af Grundtvigs unge tilhængere repræsenteret $\mathrm{i}$ denne afdeling.

Hverken Søren eller broderen P. C. Kierkegaard er repræsenteret hos Marckmann. Søren Kierkegaards Opbyggelige Taler (1843-44) burde kunne være kommet i betragtning. "Betragter man den Periode af den danske Kirkes Historie, som ligger mellem [Grundtvigs] Kirkens Genmæle (1825) og Grundloven (1849) i det Perspektiv, som Kendskabet til Eftertiden giver, kan der næppe være nogen Tvivl om, at det afgørende og centrale i Perioden er at søge dels i det Grundtvigske, dels i den gudelige Vækkelse. « ${ }^{30}$

Vi mener, at selv om man ikke kunne forvente, at Marckmann i 1844 skulle kunne se det lange kirkehistoriske perspektiv, må det have været åbenbart for ham, at hans udvalg af religiøse forfattere, som menigmand kunne have glæde og opbyggelse af at læse, var meget partisk. Marckmann (eller hans censorer i Trykkefrihedsselskabet) har ensidigt taget parti for Mynsters statskirke - the Establishment.

En af de forfattere Marckmann varmt anbefaler er Hornsyld. Af ham er der medtaget to store bøger, den ene endda fremhævet. Det er bogen Prasten Hornsyld og de Confirmerede, 2. oplag, 1832, $502 \mathrm{s.}^{31}$ Noten hertil lyder i sin helhed: "En særdeles god Folkebog, fuld af Liv og Varme" (nr. 11). Den anden bog af Hornsyld findes i Tillægget; det er Betragtninger over Bibelen, 1831-37, 3 bind på i alt 2030 sider. Den er medtaget skønt den er udsolgt. Der kan derfor nok være grund til at se lidt nøjere på Hornsyld.

Hornsyld er uden tvivl en meget from mand. Tilskyndelsen til at skrive bogen fik han, da der lød en stemme i hans inderste: "Skriv en 
Bog ud af.Dine Erfaringer og Din Virken i Dine Embeder, og kald den: Præsten Hornsyld og hans Confirmantere «. ${ }^{32}$ Således kom første udgave fra 1822 til at hedde. Bogen er ikke for børn, men for dem, som er konfirmerede. Det fremgår indirekte, at Hornsyld henvender sig til de etablerede borgere; det er hele vejen igennem tydeligt, at han regner med, at hans læsere er familjefædre og -mødre, som har husstande med tyende og børn.

Jens Hornsyld (1757-1840, pensioneret 1820) er egentlig en lærd mand, filologisk uddannet, har disputeret (for magistergraden?), men hans bøger er rent apologetiske. Han afviser uden begrundelse, men med mange småhib, (den videnskabeligt funderede) bibelkritik. For ham er Bibelen den åbenbarede sandhed, ligesom for Balle: "Bibelen forsvarer sig selv". I bogen til de konfirmerede udvikler Hornsyld kapitel for kapitel læresætningerne i Balles Lerebog.

Også politisk set er Hornsyld meget konservativ. I det store afsnit i sjette kapitel, som handler om pligterne i de enkelte stænder, begynder han med det nære - husstanden - for derfra at bevæge sig ud til Staten. Kvinden skal være manden undergiven og lydig. Men, hun lyder af. kærlighed, ikke af frygt. Manden skal dog også vise hustruen den højeste agtelse og kærlighed. Men at manden skal være den første i huset bekræftes overalt: Naturen har indrettet det sådan, at den har givet ham det kraftigere legeme og den skarpe, omfattende forstand. Der findes enkelte kvinder, hvilke sådant er givet, men de er kun undtagelser. Det ses desuden af, at der nok var kvinder som fulgte Jesus, men ingen af dem prædikede. Dog, Gud har givet kvinden den frie følelse og takt for det hjertelige og huslige. Hustruen er i sandhed Husets midtpunkt.

Forældrene skal opdrage børnene til at blive gudfrygtige, duelige borgere for Staten. Det skal helst ske på den måde, at forældrene ved deres exempel bliver et mønster for børnene, ikke ved tvang. Husbond og madmoder bør også anse deres tjenestetyende som deres børn, og disse igen husbond og madmoder som deres forældre. Men hvis de formedelst deres uforstand og barnagtige trods og nykke ikke vil lyde, så må de "opdrages ved Tvang til frivillig Lydighed . $^{33}$

Hornsyld påberåber sig af autoriteter naturligvis først og frem- 
mest Bibelen, men også landets love: Valdemars jyske lov tillader således "skjellig Brug af Kjep og Vond til Revselse, endog af Personer som staae og maae staae langt høiere i Familierne og BorgerSamfundet, end noget Tyende" (dvs. bl.a. hustruer, husmænd og lignende). Korporlig revselse bør altså visseligen være tilladt, men det skal være sindigt, ikke med voldsom adfærd. ${ }^{34}$

Mådehold er et nøgleord hos Hornsyld, men han er ikke asket. Det er tilladt at nyde. "Og Dandsen, den glædeligste og gavnligste Bevægelse med Maadehold, har ved Overdrivelse bragt Mange for Tiden [sic] i Graven. " 35 Den sande kristne er glad og tilfreds, men bør dog ikke hengive sig til en umådelig latter. Husk, at om Jesus kan vi læse, at han græd tvende gange, men aldrig at han lo. ${ }^{36}$

Tilfreds kan man i øvrigt meget vel være, selv om man er fattig. Her henviser Hornsyld bl.a. til sin fader, som levede i små kår, men som var from og glad, tilfreds med sit arbejde (han var væver). Han havde langt flere glade dage end Hornsyld selv, som ellers er kommen frem $\mathrm{i}$ verden, er en formuende mand og har nydt en lærd dannelse. ${ }^{37}$

Vi bør alle af al magt befordre Statens vel. Det sker bedst ved, at vi hver især bestræber os på at yde det bedste, vi kan inden for vores stand, og samtidig agter og ærer de andre stænder. Tyende f.eks. bør glemme egen fordel og agte på og befordre deres husbonds og madmoders. ${ }^{38}$ Sammenfattende, med Pauli ord, 1. Kor. 7,20: Hver blive i den stand, som han er kaldet til.

Hornsyld har oplevet en frygtelig periode i Danmarks og Europas historie: 1801, 1814, tabet af Norge, revolutionerne. Han beder til, at Gud vil skærme os mod alle farerne: "I Østen af Europa truer Mahomets blodrøde Maane, den er rød af Christnes Blod og bebuder rædsomme Blodbade «. ${ }^{39}$ Til i dag er denne bøn da blevet hørt.

Hornsyld er en meget vidtløftig skribent. Han bruger bevidst "den dialogiske Form «, med mange retoriske spørgsmål, og kommer ustandselig i tanker om noget, f.eks. da han i Betragtninger over Bibelen skriver om Sodomas undergang, rinder ham i hu en præstegårdsbrand, hvorom han har hørt fortælle engang i sin barndom. Han skal have været en meget - endog på højeste sted - yndet prædikant. 
Omend Marckmann næppe er hundrede procent enig med rationalisten Hornsyld i alt, falder det meste dog godt i tråd med Marckmanns og Trykkefrihedsselskabets bestræbelser. Selskabet må bygge på de etablerede borgere, som gerne skulle have trofast støtte i deres husstand.

Sammenfattende kan man sige, at mens Marckmann selv næppe har været rationalist - jævnfør de dulgte hib til Evangelisk-Kristelig Psalmebog i noten til nr. 32, så vidner meget, bl.a. den uforbeholdne tilslutning til Hornsyld, om, at rationalismen aldeles ikke er færdig i Danmark i 1840rne. Den etablerede evangeliske kirke støttes helt og fuldt. Der er intet katolsk og intet hedensk i Fortegnelsen. Man kunne et øjeblik tro, at Marckmann har gjort et faux pas, når man ser, at der er medtaget en bog med Braminske Leveregler - men man bliver hurtigt beroliget af noten, som forklarer, at skriftet "er af almindelig moralsk Indhold ", mindende om Jobs Bog (nr. 42). Der er så godt som intet af Grundtvig eller andre oppositionelle teologer. Grundtvigs fjende, H. N. Clausen, var meget centralt placeret i Trykkefrihedsselskabet. Marckmanns mor var ellers Grundtvigs kusine. Især er der ikke noget med af kristelige lægprædikanter. Rasmus Sørensen kunne udmærket godt have været repræsenteret. Han havde på dette tidspunkt udgivet adskillige små bøger om relevante emner. Bl.a. en bog om Ansgar. Bladet Almuevennen, som Rasmus Sørensen havde været medudgiver af, er ganske vist med, men Rasmus Sørensen var allerede udtrådt af redaktionen i begyndelsen af 1843. Vi har endda mistanke om, at grunden til, at John Bunyan ikke er med i Fortegnelsen, er, at hans Christens Valfart til den himmelske Stad, som fandtes i flere danske udgaver, var et overordentligt benyttet skrift i de gudelige vækkelsesbevægelser.

\section{Skrifter som meddele Kundskab om Naturen}

Dette er det mindste af de boglige afsnit, på kun 12 numre. De fleste af de bøger, som er med her, har ikke til formål blot at udvide læsernes erkendelse af naturfænomenerne, nej bøgerne har til formål at moralisere og/eller at meddele kundskaber om den nytte, mennesket kan udvinde af: naturen. En meget sigende titel er Forsøg til en kort Veiledning for Almuens Børn til at kjende Dyrenes Natur og Be- 
stemmelse og Menneskets Pligter mod dem (nr. 59). Dyrenes bestemmelse! Noten forklarer i øvrigt, at bogen er for såvel voxne som børn. Det er også sigende, at hovedsagen i Naturhistorie for Hvermand (nr. 56) dels er en beskrivelse af det menneskelige legeme, og dels de 4 husdyr: fầret, oxen, hesten og svinet, med forskrifter om hvorledes de skal behandles. Kort sagt, flere af bøgerne i dette afsnit kunne med lige så stor ret have været anbragt i afsnittet for landbrug.

En bog som er fremhævet er pastor C. L. Strøm: Naturhistorisk Lasebog for Menigmand. Udg. af Selskabet for Trykkefrihedens rette Brug. 1844, 1843. 1-2, nr. 52-53. Udover beskrivelsen af de enkelte dyreordener (med illustrationer) er der sammenfattende redegørelser for dyrenes opholdssted, for samliv mellem han og hun, for yngelens opfostring og ungernes opdragelse, deres "Formeentlige Raadslagning og Retsudøvelse«, deres tæmmelighed og lærenemhed, m.v. Næsten hele vejen igennem er dyrene betragtet i forhold til mennesket. Dette er i bd. 2 resumeret under overskriften "Fuglenes Vigtighed «. Her regnes op al den gavn, fuglene gør for mennesket, direkte og indirekte. "Endelig er det ved dem i Særdeleshed, at Naturen faaer sit rette Liv, idet de forlyste Øiet ved deres Fjers Pragt, Øret ved deres yndige Sang og Sindet ved den Livlighed og Munterhed, som er udbredt over deres hele Væsen. " De tider er altså forbi, hvor menigmand udelukkende skulle se på det rent materielle udbytte vi kan have af naturen. Men udbytte skal vi have.

\section{Historiske og statistiske Skrifter}

Afsnittet begynder med verdenshistorie, først samlede fremstillinger (10 nr.), dernæst beskrivelser af enkelte begivenheder og biografier (8 nr.). Så kommer Danmarkshistorien, igen først samlede fremstillinger (11 nr.), og dernæst værker om enkelte perioder (37 nr.).

Der fokuseres på de positive begivenheder og personer: Luther, Melanchton, Franklin. Bogtrykkeren Benjamin Franklins Liv og Levnet er skrevet af Marckmann og udgivet af Trykkefrihedsselskabet. "Franklins Liv har ikke blot historisk Betydning; men afgiver ogsaa et Mønster paa Livsviisdom, især for Folk af ringe Vilkaar, der ville 
arbeide sig frem. Denne Skildring af samme har fundet stor Udbredelse blandt Dannede og Udannede« (nr. 138). Det sidste er også sandt. Bogen kom i to oplag på i alt 8.500 exemplarer. Fra Marckmanns forord citerer vi: "... alene ved sit klare Hoved og de Dyder, han havde erhvervet sig, opnaaede han den største Lykke, som pleier at vorde Dødelige til Deel. Han blev en særdeles velhavende og anseet Mand; han blev sit Fædrelands Repræsentant ved et fremmed Hof; ja han havde det Held at gjøre store Opdagelser i Videnskaberne, han vandt et udødeligt Navn og blev en af Menneskehedens Velgjørere. Og med alt dette vedblev han dog i Sind og Gjerning at være Bogtrykkeren Benjamin Franklin. "Franklin forener i sig mange dyder: han blev velhavende, han havde fædrelandskærlighed, var flittig og nøjsom. Velstand er en dyd, fordi man så kan sørge godt for sin familje og sit tyende, og ikke ligger samfundet til last. Fædrelandskærlighed er en anden dyd, som mange af de bøger, Marckmann har med, lægger vægt på. Således er flere af bøgerne i afsnittet med (religiøse og) moralske skrifter udtrykkeligt beregnet på at vække "Fædrelandskjærlighed i de unge Hjerter" (nr. 47). Hele Danmarkshistorieafsnittet lægger vægt på de nationale begivenheder, som er egnet til at vække den rette fædrelandske ånd.

Arbejdsomhed er også en dyd, ikke mindst for fattige folk, således som det bl.a. fremgår af omtalen af Marryats fortælling om Den fattige Jack, som "ved Retskaffenhed og Dygtighed og understøttet af heldige Forhold bliver en rig, anseet og lykkelig Mand " (nr. 332). (I parentes bemærket skrev Marckmann i 1848 en bog med titlen Min Søn! om Du vil i Verden frem, så stræb! En Bog for Haandværksog Handels-Lærlinge). Men, uden kristelig ydmyghed er de andre dyder ikke meget værd. Derfor må vi savne specifikke fremstillinger af antikkens historie. De var hedninger, så derfor er der $\mathrm{i}$ det hele taget kun udgivet meget fầ ikke-videnskabelige bøger om antikken på dansk på Marckmanns tid. Den nordiske oldtid er derimod, her i Romantikkens tid, populær. Beskrivelserne af nordboernes bedrifter hjemme og ude er naturligvis med til at give os kærlighed til det fædreland, der har kunnet fostre sådanne helte.

På den anden side må vi savne fremstillinger af Tysklands, Frank- 
rigs, Englands nyere historie. Der er ingen bøger om den franske revolution med, selv om der forelå mange små og store skrifter på dansk. Heller ingen om Napoleon, skønt der forelå mange på dansk, og skønt han jo også var en fattig dreng der ved dygtighed arbejdede sig op til samfundets top. Men ydmyg var han ikke. Tyskland var der også foregået for mange uroligheder i. Med hensyn til England var sagen den, at vi endnu hadede englænderne for deres skændige overfald på os i begyndelsen af århundredet, så de eneste skrifter der forelå på dansk var faktisk skandskrifter mod englænderne.

I Danmarkshistorien har de kristelige begivenheder en stor plads. Der er således ikke mindre end tre bøger om reformationens indførelse, hvoraf de to er udgivet af Trykkefrihedsselskabet. Selskabet havde til reformationsjubilæet i 1836 udskrevet en konkurrence, hvor to af de indsendte manuskripter fandtes at være så gode, at de burde udgives. Det ene, af: L. F. Luplau, "er meget klart og fatteligt og ikke uden en vis Varme og Hjertelighed" (nr. 166). Det andet, af J. L. Rohmann, giver en »mere omfattende, grundigere og i det Hele taget bedre Skildring " og er også beregnet på "mere dannede Læsere" (nr. 168). De emner der ellers står i centrum er krigene og kongerne, naturligvis. De danske biografier, som er med, omhandler jo mest enten krigs- (især sø-)helte, statsmænd (konger) eller kristelige helte. Så bogen Absalon som Helt, Statsmand og Biskop er ikke til at komme uden om, skønt den "rigtignok (har) et noget lærd Tilsnit" (nr. 157). Der er dog også en bog med om videnskabsmanden Tycho Brahe, og en om Bertel Thorvaldsen, begge i øvrigt udgivet af Trykkefrihedsselskabet.

Sammenfattende må man sige at udvalget og annoteringen lægger vægt på historiebøgerne som opdragelsesinstrumenter. Derimod må man nok mene, at Marckmanns egen historieopfattelse hælder mod det dokumentariske, "wie es eigentlich gewesen" (Ranke 1824). Vi ved ikke om Marckmann kender dette citat, men han roser $\mathrm{fx}$. Riises Archiv (nr. 126) for troværdighed, og han har betænkeligheder ved Hauchs roman Wilhelm Zabern (som han ellers roser som en "interessant Digtning "), fordi det er "at.befrygte, at Titelen og Indledningen ville give Anledning til, at Menigmand antager Bogens Ind- 
hold for historisk Sandhed “ (nr. 355). Når Ingemanns romaner ikke fằr en sådan advarende note, skønt de blev anholdt for deres historiske ukorrekthed, skyldes det, at de klart er digtninger.

Skrifter, som meddele Oplysning og Veiledning med Hensyn til borgerlige, huuslige, oeconomiske og techniske Forhold

Den første gruppe bøger henvender sig til menigmand som samfundsborger. Vi starter et stykke nede ad rangstigen, ved sogneforstanderne, og bevæger os yderligere nogle trin nedad: sognefogeder, menige soldater, husmødre, børn, tyende, syge. Disse bøger handler om rettigheder og pligter for embedsmænd og husmødre på landet, nemlig de personer som skal opretholde ro og orden $i$ henholdsvis den offentlige og den private sfære. Der er ikke noget vedrørende de øverste stænder, eller noget specielt vedrørende "oeconomiske" forhold knyttet til byerne, handel, håndværk, industri; ikke noget vedrørende byborgernes liv. Det er typisk, at der er to lærebøger af C. E. Mangor, skønt de delvis er forældede (Mangor døde i 1801), den ene endog i den grad at den må have en advarende note med om de medikamenter den anbefaler til selvkurering, idet de "høre til de farligste Gifter" (nr. 205). Men bøgerne er meget udbredt og nyder stor anseelse blandt almuen. Derimod er ingen af svigerdatteren Madam Mangors (borgerlige) kogebøger med, skønt Kogebog for smaa Huusholdninger forelå i 6. udgave i 1844.

Så følger bøgerne om henholdsvis agerbrug, husdyrbrug og havebrug. Mange af disse bøger er udgivet af Landhusholdningsselskabet. Det er nyttige og gavnlige bøger, som der står i hveranden note. Vi citerer en typisk note: "Bestemmelsen med dette lille Skrift er at gjøre Bonden bekjendt med, hvad han har at gjøre, for at hans Hesteavl skal kunne betale sig" (Kort Veiledning til Hingstens, Folhoppens, samt Follets og Folens rigtige Behandling ..., nr. 230). Vi vil heller ikke undlade at nævne at Anviisning til Hampens Dyrkning er "et meget brugbart lille Skrift" (nr. 223).

Også havebrugsbøgerne handler kun om nyttehaver. Der er således ingen bøger med af botanisk gartner O. J. N. Mørch. Han havde bl.a. udgivet Kort Anviisning ... efter Havekonstens Regler ... 1838. 191 s. - men den handler om blomster og prydtræer. 
Skrifter til almindelig Dannelse og Underholdning

Denne del er fortegnelsens største med 136 numre, hertil kommer 4 titler fra tillægget, altså $i$ alt 140 titler, svarende til omtrent $1 / 3$ af fortegnelsens numre.

Det dobbelte dannelsesaspekt, der kan ses af Trykkefrihedsselskabets formålsparagraf, kommer også til udtryk i kategorien "dannelse og underholdning ", hvor Marckmanns valg af litteratur kan opdeles i 3 typer.

Først kommer den filantropiske og anden didaktiske almuelitteratur, svarende til den moralske dannelse, der er funderet i den kristeligt rationalistiske tradition. 48 af Marckmanns titler kan placeres her.

Sidst kommer den borgerlige litteratur, der omfatter 72 titler, og som er medium for den i formålsparagraffen nævnte æstetiske dannelse, forbedringen af smagen.

Mellem disse to typer er samlinger af eventyr og sagn placeret, med enkelte kunsteventyr imellem. Til den folkelige litteratur kan udvalgets ene folkebog (Olger Danskes historie) også regnes.

Marckmanns overskriftsformulering "almindelig Dannelse og Underholdning " er udtryk for borgerskabets almendannelsesbegreb og således egentlig i modstrid med de mange titler fra den didaktiske almuelitteratur, der med sin rettethed mod en speciel målgruppe netop ikke er almendannende. Folkeeventyrene kan derimod bedre - i deres romantiske kontekst - forstås som medium for almendannelse, idet de opfattes som udtryk for noget, der er fælles for alle klasser, for hele nationen.

I forerindringen skriver Marckmann, at almuen står på noget forskellige kulturtrin. Disse forskellige kulturtrin kan begrunde, at Marckmann på den ene side fastholder den didaktiske almuelitteratur med dens økonomiske og moralske idealer, og at han på den anden side lægger vægt på borgerlig dannelseskultur, i det omfang den ikke står over "Menigmands Sphære". Bonden, der har tilegnet sig den kristeligt-rationalistiske moral, er bl.a. af denne grund moden til den borgerligt-æstetiske dannelse.

De skrifter, der kategoriseres under didaktisk almuelitteratur, omfatter væsentligt mere end skønlitteratur. Der er en række læse- 
bøger, ugeblade, folkekalendere, 'biblioteker' og filosofiske værker, der behandler naturen, geografi, verdenshistorie, Danmarkshistorie, topografi, etnografi, landvæsen, visse politiske emner m.m. Her ligger vægten ligesom i de filantropiske almueromaner mere på "almeenvigtige Kundskaber " og moralsk belæring end på den almindelige dannelse. Det er især bonden som nyttig og dygtig samfundsborger, der fokuseres på.

I sine annotationer til denne litteraturgruppe lægger Marckmann vægt på det nyttige og det oplysende kombineret med det underholdende, dvs. det underholdende tillægges en status som middel til nytte og oplysning.

Denne didaktiske almuelitteratur kan opdeles i 2 grupper. For det første den ældre, egentligt filantropiske litteratur, hvor Marckmann har flere af de skrifter med, der figurerede i Collins liste: ${ }^{40}$

Nød- og Hjelpe-Bog for Bondestanden, eller Beskrivelse over Landsbyen Egerup i dens Lykke og Ulykke (Marckmann nr. 287, Collin s. 24).

Beskrivelse over Landsbyen Bøgelund; for Almuen og Almuevenner (Marckmann nr. 288, Collin s. 24).

Bondephilosophie, indeholdende en Samling af virkelige Tildragelser (Marckmann nr. 283, Collin s. 25).

Om Herremanden Brahe og Bønderne i Ørby (Marckmann nr. 289, Collin s. 27).

En ny og sandfardig Historie om Jesper Hansen (Marckmann nr. 290, Collin s. 27).

Christen Faursted, eller en udførlig, meget lystelig og larerig Historie om en fattig Bondekarl, der blev til en Friherre (Marckmann nr. 292, Collin s. 27).

Robinson den Yngre, en Lasebog for Ungdommen af H. Campe (Marckmann nr. 328, Collin s. 27).

For det andet har Marckmann medtaget en række nyere antologier og periodica, hvoraf nogle er udgivet af Trykkefrihedsselskabet, andre af centrale personer i Selskabet, og en enkelt fremhæver mænd fra Trykkefrihedsselskabet.

Selskabets Dansk Folkekalender for Aarene 1841, 1842, 1843, 1844 figurerer med en meget kort annotering: 
"I disse Kalendere, hvis Værd er anerkjendt, ere mange for Menigmand meget gode Stykker saavelsom Afbildninger" (nr. 272).

Lesning for Almuen (nr. 1-2, 1836-38, nr. 302) anføres uden udgiverne, der er nogle af de centrale personer i Trykkefrihedsselskabet: J. C. Drewsen, J. P. Mynster, J. F. Schouw og H. C. Ørsted. Kritikeren P. Hjort var ligeledes medlem af Trykkefrihedsselskabet, hans Den danske Borneven, en Lasebog for Borger- og Almueskoler (3. udg. 1842, nr. 263) fremhæves også af Marckmann. For denne gælder det, at "Stilen er reen og uden barnlig Maneer" og den "meddeler et Indbegreb af de almeenvigtigste Kundskaber".

Skandinavisk Folkekalender for 1843 og 1844, udgiv. af L. Moltke får en annotation, der fremhæver Trykkefrihedsselskabets "fædrelandsksindede Mænd «:

"Det Vigtigste af Indholdet er endeel Biographier med Portraiter af fædrelandsksindede Mænd: Schouw, Clausen, Drewsen, Hvidt, Lehmann, P. H. Lorentzen" (nr. 273).

Det er specielt værd at bemærke, at Marckmann optager Almuevennen, udgivet af J. A. Hansen (nr. 271). Almuevennen kritiserede enevælden og godsejerprivilegierne samt behandlede debatterne i de rådgivende stænderforsamlinger. Marckmanns Et Brev om det politiske Røre i Folket, som han publicerede under pseudonymet J. Olbe, var blevet genoptrykt i Almuevennen 1843. I Folkebibliotekernes forgangere oplyser Helge Nielsen, at læseforeningen i Sorterup-Ottestrup (ved Slagelse) i 1850 fik afslag på støtte fra Landhusholdningsselskabet, fordi foreningen havde 3 årgange af »det fordærvelige Blad ", Almuevennen. ${ }^{41}$

Af andre periodica med megen "statsborgerlig Oplysning" kan nævnes Morskabslasning for den danske Almue, et ugeskrift udgivet af H. K. Rask (1.-2. årgang, 1839-41, nr. 300). Marckmann noterer:

"Restoplaget af et ophørt Blad, der, medens det udgaves, var yndet af Bonden." 
Bladet fortsatte dog til 1846. Dansk litteraturhistorie (1984) skriver om det:

"Her indførte han (H. K. Rask) en rubrik med præsentation og forklaring af tidens nye ord og begreber: demokrati, demagog, petition, nepotisme, debat, argument, motiv, aktie, nationalitet, adresse, effect, intolerance, appellere - og selvfølgelig også emancipation. ${ }^{42}$

Dansk litteraturhistorie citerer endvidere en tekst af H. K. Rask, hvor han beklager, at bladet kun udbredes lidet hos almuen. ${ }^{43}$ Marckmanns oplysning om, at det var yndet af bonden, strider altså mod Rasks eget udsagn.

\section{Samlinger af eventyr og sagn}

Holdningen til folkeboger $i$ Trykkefrihedsselskabet

I fortegnelsen er der 19 samlinger af eventyr og sagn. Disse dækker en stor del af verden. Til de optegnede folkeeventyr og folkesagn kommer en samling eventyr af $\mathrm{H}$. C. Andersen og en samling eventyr af Oehlenschläger (henholdsvis nr. 315 og nr. 321). Trykkefrihedsselskabets egen udgivelse af Oehlenschlägers Nordiske Oldsagn, bearbeidede til Almeenlasning (nr. 311) er naturligvis med, som alle Selskabets andre udgivelser.

I sine annotationer til eventyrene er Marckmann gennemgående ret kortfattet og beskrivende. Beskrivelserne går på, hvor eventyrene stammer fra og hvordan de er bearbejdede. Hertil kommer, at Marckmann gentagne gange bemærker, at de læses af "Almuen" eller af "Menigmand " med megen interesse. Rækken af folkeeventyr afspejler et træk ved romantikken: interessen for folkedybet og folkesjælen. Marckmanns præferencer synes - vurderet ud fra annotationerne - dog at ligge på kunsteventyrene og Oehlenschlägers gendigtninger.

Der er kun én eventyrsamling af H. C. Andersen: Nye Eventyr (1844); men denne er fremhævet med store typer. Annotationen lyder i sin helhed således: 
"Disse skjønne Digtninger ville med deres Naivitet, Vid, Humor og Lune upaatvivlelig tiltale alle, endog den Simpleste. Det er ikke Folkesagnet, Forfatteren her har behandlet, men baade Stoffet og Bearbeidelsen tilhører ham selv« (nr. 315).

I annotationen er der en positiv æstetisk vurdering, hvad der ikke er af de egentlige folkeeventyr. H. C. Andersens digteriske individualitet gøres også til en kvalitet, der implicit sættes over for folkeeventyrene. Noget tilsvarende fremgår af annoteringen til Musæus' Folkeeventyr, der ikke er "Folkeeventyr i strængere Forstand, men Digtninger af Musæus « (nr. 320).

Oehlenschlägers bearbejdelse af nordiske oldsagn blev ikke betragtet som helt uproblematisk af den komité, der bedømte den for Trykkefrihedsselskabet. Komiteen bestod af H. N. Clausen, H. C. Ørsted og F.C. Olsen. Ifølge Comiteebetcenkningen har Oehlenschläger udvalgt det interessanteste af stoffet og forkortet det:

"Saaledes træde disse ældgamle Sagn frem i deres oprindelige Simpelhed, men derfor ogsaa med det utilhyllede Præg af Raahed, som var hine Tider egen.

Det er da muligt, at adskillige Steder i Bogen ville være mindre tiltalende for dem, der ere vante til at see Oldtidens Liv igjennem de nyere Digteres Værker, hvor det mildnes og forskjønnes ved Tilblanding af en dannet Tidsalders Indhold. “ ${ }^{44}$

Problemet er den "Raahed ", som de nordiske oldsagn fremtræder med, eller anderledes formuleret: manglen på dannelse. Komiteens medlemmer ser dog også noget positivt i en "saa stor Umiddelbarhed «, nemlig at den sætter deres egen tid i relief. Afslutningen på betænkningen er, at det ikke er tilrådeligt at udgive endnu et bind, som det ellers var planlagt.

Råheden og umiddelbarheden i disse folkesagn ligger dog langt fra, hvad nogle folkebøger rummede. I forlængelse af den filantropiske oplysningstradition har Marckmanns fortegnelse med en enkelt undtagelse udelukket folkebøgerne. Undtagelsen er Olger Danskes Krønike, som blev udgivet af Trykkefrihedsselskabet i 1842 (nr. 389). 
Denne udgivelse rejste kritik. I referatet af repræsentantforsamlingen den 25. november 1842 omtales det, ${ }^{45}$ at udgivelsen af Olger Danske er blevet heftigt angrebet i Kjobenhavnsposten. I Dansk Folkeblad forsvares udgivelsen. Forsvaret indledes på en måde, der markerer Trykkefrihedsselskabets holdning til nogle folkelige genrer, herunder folkebøgerne (allehånde gamle krøniker):

"Det har maaske været flere af Trykkefrihedsselskabets Medlemmer paafaldende, at Selskabet har foranstaltet en ny Udgave af et Skrift, som man er vant til at see falbudt hos Triblers Enke imellem allehaande gamle Krøniker, lystelige at læse, nye sørgelige Viser, sandfærdige Drømmetydere o.s.v. « ${ }^{46}$

"M. H. « forsvarer udgivelsen med en række argumenter. Skriftet kan være med til at opfylde "de mindre Dannedes boglige Fornødenheder «, det er morskabslæsning, der kan »vække og nære Læselysten ", bogens stof har en "halvt" national karakter og rummer en form for historisk sandhed, og dens elementer af overtro kan ikke mere betragtes som skadelige, fordi overtroen i næsten et århundrede er blevet bearbejdet af "Oplysningsmændene». Det fremhæves også, at bogen er nedsunket kulturgods og at oversætteren Christiern Pedersen var en ypperlig prosaist, der var modstander af det "Flensborgerdanske". Olger Danskes Kronike kommer således især på grund af det nationalt tolkede indhold til at udskille sig fra de øvrige folkebøger, der stred mod moralen og dannelsesidealerne.

\section{Dannelseslitteraturen}

Dannelseslitteraturen er repræsenteret med en række genrer: den borgerlige roman (oversatte værker) med 24 titler; danske romaner og noveller, primært guldalderlitteratur med 16 titler; danske og udenlandske satiriske skrifter med 5 titler; komedier og vaudeviller, primært Holberg, med 9 titler; danske syngespil og romantiske skuespil med 7 titler; poesi med 9 titler; samt et par samlinger fabler.

For den borgerlige romans vedkommende dominerer Marryat, Cooper og Walter Scott, hertil kommer Dickens' Oliver Twist og repræsentanter for oplysningstidens borgerlige roman: Oliver 
Goldsmith, Smollett, Swift og Defoe. Det, der fremhæves i annotationerne, er det underholdende, det folkelige, det ikke anstødelige og moralen. Midlothians Hjerte af Scott (nr. 340) "efterlader et godt moralsk Indtryk ", Marryats Den fattige Jack (nr. 332) »Fortæller, hvorledes en fattig engelsk Matrosdreng ved Retskaffenhed og Dygtighed og understøttet af heldige Forhold bliver en rig, anseet og lykkelig Mand «.

Marckmann har på den ene side udgrænset mere oprørske romantikere som Hugo, hvis (dengang) samlede romaner udkom på dansk 1830-32, og mere 'umoralske' 1700-talsforfattere som Fielding (danske udgaver af Tom Jones fra 1781 og 1813); på den anden side har han udgrænset lejebibliotekslitteraturen à la Paul de Kochs Henry Blemont eller Hanrejen 1837-38. Det første kan Marckmann i nogen grad have gode grunde til, disse typer forfatterskaber kan hævdes at ligger over "Menigmands Sphære«; men på den anden side kan politiske og moralske grunde have spillet en rolle.

Med hensyn til 'lejebibliotekslitteraturen' har eksponenter for Trykkefrihedsselskabet udtrykt sig klart. I en anonym artikel i Dansk Folkeblad 1841 med titlen Forslag til bedre Leiebibliotheker frygtes det så småt, "at Verden skal forgaae af daarlige Romaner «. Disse dårlige romaner er opium for folket:

"Den blinde og daarlige Selvhengivelse, hvormed saa Mangfoldige sluge det ene efter det andet af disse usle og kjærneløse, ofte endog giftige Producter, hvoraf en fornuftig og dannet Mand eller Qvinde ikke kunde udholde at læse faa Sider, er tilforn i Folkebladet bleven sammenlignet med Østerlændernes Opiumspisen, og turde vel baade i sit Væsen og Virkninger have en dybere Lighed dermed. « ${ }^{47}$

En anden kommentar tidligere samme år i Dansk Folkeblad har et tilsvarende synspunkt og kommer også ind på de dårlige oversættelser:

"Som bekjendt, lider vor Literatur, og har længe lidt af en stor Mængde slette Oversættelser af tydske, franske og engelske Morskabsbøger, der aarlig forøges med flere og ikke mangle Kjøbere og 
Læsere, skjøndt den Uvidenhed, Tankeløshed og Smagløshed, der ofte røber sig i disse Oversættelser, og den skjødesløse Behandling, hvormed de i det Hele affærdiges, maa gjøre dem modbydelige for enhver Læser, som fordrer en bedre Nydelse af en Roman end den blotte, man kunde i en vis Henseende sige, halv dyriske Sjæls-Pirring eller -Spænding ved Læsningen. « ${ }^{48}$

Fra Fadrelandets anmeldelse af en fransk roman, Michel Massons Jomfru og Martyrinde, $1840,{ }^{49}$ trækker kommentaren nogle oversættelsesfejl frem. "Son Guide du jeune botaniste à la main" (med sin vejledning for unge botanikere $\mathrm{i}$ hånden) oversættes "Ledsaget af en ung Urtekyndig, der hørte til Huset «. "Dans le corps des officiers " (i officersstanden) oversættes til "I en Officers Legeme (og der fortsættes:) bør man ikke taale en Morders, en Giftblanders Nærværelse".

For Marckmann som for mange andre i Trykkefrihedsselskabet var lejebiblioteksromanerne det største onde og dermed det, det var vigtigst at bekæmpe.

I Om Menigmands Oplysning skriver Marckmann i sin fiktive kammerrådsidentitet:

"Jeg har selv læst mange gode Ting i mit Liv og havt Hovedet fuldt deraf, og jeg kan endnu med Fornøielse tage min gamle Horats for $\operatorname{mig},(\ldots) \ll{ }^{50}$

Den dannede kan søge til den klassiske antikke litteratur; men denne litteratur falder helt uden for "Menigmands Sphære». Den hedenske, antikke litteratur rummer hverken den moral eller de dannelseselementer, der anses for at være adækvate for almuen. Der var mange oversættelser af antikke værker på Marckmanns tid.

Den danske litteratur, der er med i fortegnelsen, er overvejende nationalromantisk, med Holberg som en markant undtagelse (10 numre).Med hensyn til Ingemanns historiske romaner og værker af Oehlenschläger er der ingen tvivl om værdien; men der er derimod nogen tvivl om tilgængeligheden. Ingemanns fortællinger er "temmelig sammensatte i deres Bygning " (nr. 350-54) og nogle af Oehlenschlägers værker (Sanct Hansaften-Spil fieks.) »indeholder vistnok 
meget, som vil tiltale Folket, men ogsaa meget, som dette neppe forstaaer " (nr. 379). Det nationale hos Oehlenschläger og Ingemann betoner Marckmann mindre end det bliver gjort i omtaler i Folkebladet. Heri står der således om Oehlenschläger:

"Den nationale Digter er en af de store Løftestænger, hvorved Folkelivet hæves og føres frem i sin Udvikling. Han optager i sig Minderne om Fædrenes Kraft og Storhed, hans Sjæl er det Gjæmmested, hvor den nationale Følelse og de fædrelandske Toner, som adspredt røre sig hos de Enkelte, samles og forenes, for gjenfødte og forædlede at overantvordes til Folket igjen. " ${ }^{51}$

Marckmann annoterer stort set ikke Holbergs værker, hvilket må tolkes som udtryk for, at han forudsætter dem kendte af bestyrerne for sognebogsamlingerne.

Mellem Holberg og Oehlenschläger - litteraturhistorisk set - har Marckmann kun medtaget værker af et par af oplysningstidens mindre kendte, danske forfattere: L. C. Sander og T. Thaarup. Den førstnævntes "Sørgespil " Niels Ebbesen af Nørreriis (nr. 383), tillægges ikke så megen "poetisk Værd " som Hertz' Svend Dyrings Huus (nr. 381) og J. L. Heibergs Elverhøi (nr. 382); men dets "vakkert behandlede Emne er af saa stor nationalhistorisk Betydning".

At P. A. Heiberg ikke er med i Marckmanns udvalg er ikke overraskende, Rahbek og Schack Staffeldt kunne næppe heller komme i betragtning ud fra Marckmanns kriterier; men Baggesens, Ewalds og Wessels fravær falder lidt i øjnene. Ewalds Fiskerne kunne f.eks. umiddelbart set egne sig til fortegnelsen pga. den idealiserede fremstilling af almuen.

Ud over Ingemann er den med Marckmann samtidige danske litteratur repræsenteret af Chr. Winther (nr. 356), hvis fortællinger karakteriseres som "skjønne nationale«, Carsten Hauch, Carit Etlar, St. St. Blicher og et par nu mindre kendte. Blicher er repræsenteret med 4 numre, der samlet făr en meget kort annotation:

"Det Meste af disse bekjendte Skrifters Indhold maa vistnok anbefales til nærværende Øiemed» (nr. 357-60). 
Der er et lille forbehold over for Blichers poetiske realisme. 'Byrealisterne' Carl Bagger og fru Gyllembourg er heller ikke med. Det samme gælder Poul Martin Møller og Goldschmidt. Kaalunds tidligste værker kunne også have været på tale. Sammenfattende kan det siges, at Marckmann fầr afgrænset menigmands litterære og dannelsesmæssige sfære til den filantropiske og didaktiske almuelitteratur, folkeeventyrene, den mindre radikale og mere moralske del af den borgerlige roman, samt Holberg og den harmoniske, nationale del af den danske guldalderlitteratur.

Marckmann udgrænser folkebøgerne, de "usædelige " lejebiblioteksromaner og den dannelseslitteratur, der er mere radikal, mere kritisk, foruroligende eller som tematiserer splittelse og bryder med de harmonisk-nationale værdier.

\section{Marckmann som bibliograf}

Marckmann virker meget velorienteret $i$ hele den aktuelle danske litteratur. Han har mange gode gamle bøger med (og nogle mindre gode, men de fầr så et advarende ord i noten). Han er også up to date. Der er ikke så få bøger med fra 1844, hans eget udgivelsesår. Han tager de sædvanlige forbehold med hensyn til fuldstændighed inden for sine rammer, men han har åbenbart været en flittig læser af datidens vigtigste bibliografier: forlagskataloger, og en flittig gæst $i$ de københavnske boghandeler (s. VIII-IX). Vi tør gå ud fra, at når han har udeladt en bog, så er det bevidst.

Noget af udvalget har givet sig selv: alle Trykkefrihedsselskabets skrifter, med undtagelse af Dansk Folkeblad, er naturligvis med. Yderligere en del af de medtagne bøger, som ikke er udgivet af Selskabet, har det haft på lager. Men de er ikke derfor hævet over kritik. Om P. L. Møllers bog om bogtrykkerkunstens historie hedder det således, at sproget $\mathrm{i}$ den ikke er så let og simpelt som $\mathrm{i}$ Selskabets andre skrifter (nr. 131). Videre er der medtaget særdeles mange af Landhusholdningsselskabets bøger. Også selv om nogle af dem er gamle, delvis forældede, og erstattede af nyere bøger. Det synes, at Marckmann har taget hensyn til at disse bøger i forvejen er udbredt blandt almuen, og at han derfor ikke vil forbigå dem. 
Endnu et fingerpeg om at han henvender sig til landbefolkningen, ikke til bybefolkningen.

Videre optager amts- og købstadstopografierne mange numre (nr. 82-120); har man en, må man vel tage dem alle med. Men der er ingen om hovedstaden.

Marckmann er meget bevidst om, hvilke værdier han vil give almuen, som vi fx kunne se det i udvalget af de æstetiske skrifter. Men han er også klar over, at han må slå af på fordringerne, indtil almuen har lært noget mere. "Bogen er just ikke skreven med Aand; men Menigmand læser den dog gjerne", som han skriver om Viisdomsbog for den christelige Landmand (nr. 40).

\section{Marckmanns annotationer}

Marckmanns arbejde med annoteringen af bøgerne repræsenterer en helt original indsats som mange nutidige udarbejdere af boglister kunne lære en del af: Først og fremmest er han ikke bleg for at fremsætte en explicit vurdering af bøgerne, både positiv og negativ kritik; både med hensyn til deres faglige og xstetiske indhold, og især med hensyn til deres anvendelighed.

Til en del bøger er der ingen noter. Som Marckmann selv forklarer: enten fordi der intet særskilt er at bemærke, eller fordi de er så almindeligt bekendte at al nærmere omtale måtte anses for overflødig (s. VIII). Det sidste er fx uden tvivl grunden til, at Ingemanns romaner kun făr én kort, samlet note. Marckmann er meget opmærksom på sproglige vanskeligheder $\mathrm{i}$ bøgerne. Han har $\mathrm{i}$ de senere år konstateret en beklagelig tendens hos forfatterne til at anvende kunstige vendinger og sammenføjninger og hyppig brug af fremmedord. Det gør at "Kløften, som skiller Folket fra Litteraturen, truer med stedse at blive større» (s. X).

Det der gør Marckmann til den fremragende annotatør for folket er, at han anviser måder, hvorpå formidleren eller læseren selv kan overkomme forståelses- og læsevanskelighederne. Han giver utallige steder $\mathrm{i}$ fortegnelsen det, som vi med et udtryk lånt fra den socialistiske bibliografiske teori kan kalde "pædagogiske vink «. Fx er Eschrichts bog om Det menneskelige Øie en interessant bog, men vanskelig materie. Bogen vil »hensigtsmæssigen kunne benyttes ved 


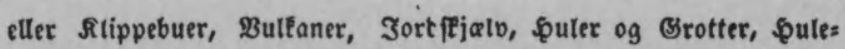
templer og Ratalomber, Miner og Bruber etc. Foruben Nebbe= telfer om be alminbelige forbold veb (3jenftandene og penviisninger til Raturlobene finbes ber en Mangbe betaillerebe $\mathfrak{B}$ effrivelfer over fvecielle şbonomener og Begibenteber, titbects ubbrag af Reifebe= ferivelfer. $\mathfrak{I}$ ben alminbeligere Deet af bette 3 nbboto er 8 remftils lingen iffé faa popular, fom bet var onfectigt, berimob er bette Zilfalbet meb Senfinn til bet mere Specielle, fom ubgier ben langt overveienbe Deel af 20 ogen, og fom ubentvibl hoilig vil interçfere Menigmanb. Brugen af fremmebe vibenfeabelige ubtrnt er tem= metig byppig. En Forllaring af be minbre befjenbte faavelfom fremmebe Maal = og 2 axgtangivelfer, fom tibt ere benyttebe, bar Forfatteren tilfeiet $i$ et 2 nbang.

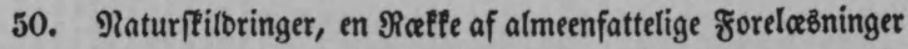
af ร. ₹. S丸)urw; meb 2 Robbertabler. 2ben Urgave. 1839.

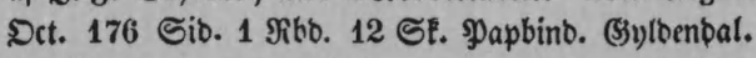

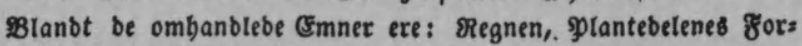
vanbling, Forverbenens planter, פalmerne, Bjerguantringer $i$ Rorben og Syben, Etna, Raturen $i$ Rorb $=$ og Sybafrica og paa Snbbavzвerne, Raffetraet, Sufterreret, Theebuffen etc. Forfatte: renz beljente Rlarbeo og Simplicitet gienfinber man ogfaa ber.

51. Det menneffelige șdie, fremftillet ved D. $\mathfrak{F}$. (E) giv. af Selfe. f. IrrvtEefr. r. $2 B r .1843$. Dct. 72 Sib. 28 Se. beft. Selift.

En interebfant $280 \mathrm{~g}$, ber bar til senfigt oat give et Exempet paa bet mennefetige Regemb unberfulbe Bigning og vaffe Jnter= eहfe for אuunbfeaben om famme". Forebraget er Flart og $i$ bet sele fatteligt; men Materien for fammenfat, til at $B o g e n$ fan faftbolde Eafere af Folfetlabien, ber ftaae paa be vingere Irin af Dan= nelfe; iljoorvel benne Dmftanbigheb bavees noget berveb, at ben mere ubforlige Fremftilling ofte meb minore Stiil er flubt inb imellem Jerten og tail fpringeb ober. For 2umuen $i$ xtminbelig=

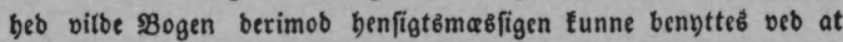
forelafez og forflares, bvarybos গ̧banomenet, fom ligger tit Brunb for soletb Jnoretning, maatte forcvifę.

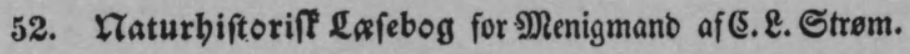


at forelæses og forklares, hvorhos Phænomenet, som ligger til Grund for Øiets Indretning, maatte forevises « (nr. 51).

Bierings Popular Larebog i Mechanik (1844) er nok for svær for menigmand i almindelighed; "derimod vil den vistnok egne sig for 'de meest oplyste unge Mænd af Landsbymenighederne,' saavelsom for Skolelærere, og saaledes middelbart [vores understregning] gjennem disse kunne komme Menigmand tilgode" (nr. 403).

Han har også i flere tilfælde mere end een bog med om samme emne. Fx er der både en udførlig, men ikke ganske let fremstilling om engvanding, og en pjece på 15 sider om samme emne. Den sidste er da "meget hensigtsmæssig som Indledning" til den større bog (nr. 220-21).

Videre gør Marckmann meget ud af at sætte de medtagne bøger i forhold til hinanden. Han prøver at fremhæve det som er karakteristisk for den enkelte bog, men samtidig viser han hvorved den adskiller sig fra andre, tilsvarende bøger. Hertil anvender han ofte det som i nyere bibliografisk teori kaldes samleannotationer, altså én annotation fælles for flere numre. Det er både pladsbesparende og ofte sagligt bedre end at give to eller flere noter. Således ved de ovennævnte bøger om engvanding.

Der er mange praktiske vink til bibliotekarerne, både i noterne og i Anhanget. Ikke mindst med hensyn til en økonomisk forvaltning af bibliotekerne. Ofte bliver en bestemt bogs værdi sat i forhold til købsprisen, det være sig at Marckmann synes at prisen er for høj i forhold til værdien, eller omvendt. Om flere af de udsolgte bøger angives den omtrentlige antikvariske pris. Flere gange sukker han over at nogle udgaver rummer flere værker, hvorved man kan komme til at betale for værker, som ikke er relevante ( $\mathrm{fx}$ nr. 380). Omvendt giver han gode råd om udgaven af Holbergs samtlige Comoedier $i$ eet Bind: "Saaledes som denne Udgave erholdes i Bogladerne, er den naturligviis ikke beqvem for Sognebibliothekerne, da den kun kan udlaanes til Een; men denne Ubeqvemmelighed kan hæves, idet Bogen lader sig indbinde i flere Hefter» (nr. 371).

I sin "monsterfortegnelse" giver Marckmann ofte padagogiske anvisninger på, hvorledes bogerne bedst benyttes, således her $i$ kommentaren til Eschrichts Det menneskelige Øie. 
Marckmann henvender sig, som der står på titelbladet, fornemmelig til bestyrere af sognebiblioteker, ikke direkte til den menige mand. Det fremgår også mange steder i noterne, at fortegnelsen dels er tænkt som en indkøbsvejleding, og dels som en formidlingsvejledning.

Målgruppen er altså bondestanden eller landalmuen, som Marckmann selv skriver s. VI-VIII. Man kan undre sig over at Marckmann og Trykkefrihedsselskabet ikke interesserer sig for byalmuen. Marckmann er udmærket godt klar over at der ingen biblioteker er for almuen i byerne, bortset fra lejebibliotekerne, og dem er han meget kritisk overfor (anm. på s. VI). De fattigste har nok ikke haft råd til at benytte dem. Man kan også undre sig over at fortegnelsen slet ikke henvender sig til børn. Videre fremgår det mere indirekte af flere ting, at heller ikke de fattigste på landet formodentlig har været med blandt dem, der benyttede sognebibliotekerne. Således nævnes det, at sognebibliotekerne sædvanligvis dannes ved at der oprettes en forening, hvis medlemmer via et startindskud og årligt kontingent sikrer indkøb af bøger. De bidragydende medlemmer af foreningen danner en generalforsamling. "For at ogsaa de mindre Formuende kunne blive Medlemmer af saadanne Foreninger og faae Adgang til Læsning, har man paa mange Steder bestemt, at Huusmænd og Tjenestefolk kun behøve at erlægge en vis Deel af det sædvanlige Bidrag " (s. 106). Men det har man altså ikke alle steder bestemt. Desuden har de fattigste på landet (de jordløse) næppe haft tid og har måske ikke engang kunnet læse.

Den egentlige målgruppe er så bønderne, de mennesker på landet som har ejet fast ejendom, men ikke byboer, ikke børn, og ikke de jordløse. Forklaringen herpå kan meget vel være, at de eneste mennesker der betød noget politisk på den tid var mænd, der besad ejendom af en vis værdi. Der var i Kongeriget kun i alt 32.000 mænd der havde valgret til stæenderforsamlingerne. ${ }^{52}$ De fleste af byboerne heriblandt har Selskabet måske allerede haft som medlemmer (langt de fleste af Selskabets flere tusinde medlemmer var byboere). Men bønderne udgjorde i 1845 kun 2,3\% eller 79 personer af Selskabets medlemsskare. Derfor gjaldt det for Trykkefrihedsselskabets mænd om at fầ udbredt deres ideer til bønderne på anden måde. Hertil måtte bibliotekerne være et virksomt middel. 


\section{NOTER}

1. Marckmann, J. W.: Fortegnelse over Skrifter til Læsning for Menigmand, fornemmelig til Brug for Bestyrere af Sognebibliotheker, med et Anhang om Sognebibliotheker. Udg. af Selskabet for Trykkefrihedens rette Brug. Kjbh., 1844. X, $109 \mathrm{~s}$.

Forerindring s. V-X

Selve Fortegnelsen s. 1-87

Register s. 88-101

Anhang om Sognebibliotheker s. 105-09.

2. Citeret efter Danmarks historie / Under redaktion af John Danstrup og Hal Koch. Bd. 11, s. 157. Kbh.: Politikens Forlag, 1971. - (Parafrasen ovenfor om "Skrivefrækheden « bygger på et citat på s. 156).

3. S. 334-35 i Sigurd Nielsen: Selskabet til Trykkefrihedens rette Brug. - I: Historiske Meddelelser om København, 4. rk., 4. bd., 1954-57, s. 225-364.

4. Sigurd Nielsen, anf. skr., s. 336.

5. Rigsarkivet, Trykkefrihedsselskabets forhandlingsprotokol 1837-44, s. 254-55.

6. Citeret efter Sigurd Nielsen, anf. skr., s. 234.

7. Dansk Folkeblad, 1841, nr. 22.

8. Trykkefrihedsselskabets biblioteksindsats er meget koncist behandlet i Helge Nielsen: Folkebibliotekernes forgængere : oplysning, almue- og borgerbiblioteker fra 1770erne til 1834. Kbh., 1960, s. 608-10.

9. Artiklen "Om Læseforeninger blandt Landalmuen«, Dansk Folkeblad, 1836, nr. 5, side 18. - Hele denne artikel, bortset fra den afsluttende paragraf, er optrykt i Vulgaritetens polering : en tekstantologi ... Udg. af Povl Schmidt. Odense, 1980, s. 42-48.

10. Paul de Koch: Henry Blemont eller Hanreien. Udgivet som bind 1-2 af Paul de Kochs "Samlede Skrifter", 1837-38. - Sigurd Nielsen, anf. skr., s. 287.

11. Om Marckmann og hans fortegnelse se i øvrigt bl.a.: Erslew: Forfatter-Lexicon. - Dansk Biografisk Leksikon. 2. udg. (i 3. udg. kun kort omtale). - Sigfred Hjort Eriksen: En dansk Fælles-Katalog fylder 100 Aar! I: Bogens Verden, årg. 26, 1944, s. 144-151. - Povl Schmidt: Litteratur for menigmand. 2. udg. Odense, 1982, s. 39-46.

12. Dansk Folkeblad, 1839, nr. 30-31, s. 123.

13. Samme, s. 124.

14. Almuevennen, 1843 , nr. 40 , s. (1-3).

15. Samme, s. (1).

16. Sigurd Nielsen, anf. skr., s. 325.

17. Samme, s. 325-26. - Referat af bestyrelsesmøde i Dansk Folkeblad, 1839, nr. 32, s. 128. - Beretning om Selskabet for Trykkefrihedens rette Brug i Tillægsblad til Dansk Folkeblad, 6. årg., nr. 6-7, s. V.

18. Sigurd Nielsen, anf. skr., s. 327. - Dansk Folkeblad, 1841, nr. 10-11, s. 37 med titlen "Bogfortegnelse til Veiledning for Sognebibliotheker". 
19. Protokollen 15. marts 1842.

20. Tillægsblad til Dansk Folkeblad, 8. årg., nr. 7.

21. Protokollen 3. april 1844.

22. Sigurd Nielsen, anf. skr., s. 327-28.

23. Marckmann: Fortegnelse over Skrifter ..., s. VI-VII.

24. Nr. + tal i parentes henviser til løbenumrene i Marckmanns Fortegnelse.

25. Marckmann, anf. skr., s. VII.

26. P. G. Lindhardt: Bibelen og det danske Folk. 1942.

27. P. Skautrup: Det danske sprogs historie. Bd. 3, 1953, s. 258.

28. Lindhardt, anf. skr., s. 59-60.

29. Hal Koch: Den danske Kirkes Historie, bd. 6, 1954, s. 239.

30. Samme, s. 285.

31. Jens Hornsyld: Præsten Hornsyld og de Confirmerede, eller Taler og Samtaler over Lærebogen i den evangelisk-christelige Religion, en Haandbog for Christne i Livets forskjellige Stillinger. 2. opl. Kbh., 1832.

32. Samme, s. VI.

33. Samme, s. 289.

34. Samme, s. 363 .

35. Samme, s. 320 .

36. Samme, s. 338 .

37. Samme, s. 330-31.

38. Samme, s. 365 .

39. Samme, s. 499.

40. Fortegnelse over Skrifter passende for den dansk-norske Landalmue. Kbh., 1807.

41. Helge Nielsen, anf. skr., s. 241-42.

42. Dansk litteraturhistorie, bd. 5, 1984, s. 32.

43. Dansk litteraturhistorie, bd. 5, 1984, s. 33, citerer Rask for følgende: „I blandt Almuen er jeg født og opvoxen, og jeg kjender alt fra min Barndom den store Trang, der er til Bøger, som ret kan tiltale dens Sands og Smag, og som ere skikkede til at forelæses om Vinteraftenen i den lune Stue (...) Bladet holdes for Tiden fornemmelig af mine gamle Venner eller i min nærmeste Omegn af. Velvillie imod mig; men det udbredes lidet i blandt Almuen, og det er for dem, jeg ønsker at skrive, dem, jeg ønsker at levere en morsom og nyttig Læsning. «

44. Betænkningen er trykt i Dansk Folkeblad, 1840, nr. 55.

45. Samme, 1842, nr. 41-42.

46. Samme, 1842, nr. 31.

47. Samme, $1841, \mathrm{nr}$. 46-47.

48. Samme, 1841, nr. 7.

49. Michel Masson: Jomfru og Martyrinde / Overs. fra det Franske ved L. Philip og C. Lund. Deel 1-2. Kbh., 1840.

50. Dansk Folkeblad, 1839, nr. 32.

51. Samme, 1841, nr. 40.

52. Danmarks historie, bd. 5. Af Vagn Skovgaard-Petersen. Gyldendal, 1985. S. 41. 